DOCTRINA

\title{
Una interpretación alternativa a la justificación de garantías penales en el derecho administrativo sancionador para Chile
}

\author{
An alternative interpretation to the provision of criminal Guarantees \\ in the Administrative sanctions for Chile
}

\author{
Pedro Aracena Salgado \\ Abogado, Chile
}

RESUMEN Este artículo ofrece una breve descripción sobre la aplicación de garantías fundamentales (penales) a los ciudadanos en los procedimientos administrativos de sanción, con apoyo de algunos pronunciamientos de los tribunales chilenos de justicia. A continuación se propone abandonar derechamente la búsqueda de una (supuesta) «identidad natural u ontológica» entre la infracción administrativa y el delito penal. Bajo esas premisas se concluye que una comprensión racional de las herramientas que posee la Administración, para determinar a bien su cometido, puede ayudar - por finen una clarificación de la histórica relación entre sanción administrativa y pena.

PALABRAS CLAVE Derecho administrativo sancionador, derecho penal, garantías fundamentales, infracción administrativa y delito penal.

ABSTRACT This paper provides a brief description of the state of affairs on the issue of implementation of fundamental rights of the citizens in administrative penalty procedures, based on some statements of the Chilean courts of justice. Here it is propose uprightly to abandon the search for a «supposed natural or ontological identity» between administrative offense and criminal offense. Under these assumptions, we conclude that a rational understanding of the tools that the administration has, to determine their duties, can finally help as a clarification of the historical relationship between administrative penalty and punishment.

KEYWORS Administrative law penalties, criminal law, fundamental guarantees, sanctioning administrative offense and criminal offense. 


\section{Introducción}

La discusión relativa al vínculo entre derecho penal y derecho administrativo sancionador es de larga data. Son numerosas las publicaciones extranjeras ${ }^{1}$ y nacionales, desde el ámbito penal ${ }^{2}$ o administrativo ${ }^{3}$ que han intentado abordar las siguientes preguntas: ¿Qué garantías y/o principios deben ordenar el procedimiento administrativo sancionatorio? ¿Qué relación tienen los binomios infracción/sanción (administrativa) y delito/pena? Y quizá más relevante, ¿ debe al jurista concernir la respuesta a esta duda para contestar acertadamente qué garantías sustantivas y/o adjetivas deben informar el administrativo sancionador?

Adelantamos desde ya que una comprensión acertada ${ }^{4}$ de las sanciones administrativas como herramientas de regulación del sistema social — mas no como una potestad similar a la penal- permite inclinarse por la negativa.

Empero, es comprensible que en Chile se sostenga con vigor que la potestad sancionadora administrativa ${ }^{5}$ se circunscribe inserta en el ius puniendi estatal. $Y$ es que, a nuestro juicio, parecen encontrarse opiniones que terminan por privilegiar el interés privado ${ }^{6}$ por sobre el interés público. ${ }^{7}$ En este sentido, un autor nacional ha expresado:

1. Cf. Cerezo (1981: 49), Jakobs (1997), Merkl (2004), Nieto (2005), Santamaría (2009), García de Enterría y Fernández (2002) y Roxin (1997).

2. Desde la ciencia penal, un visionario es Rodríguez Collao (1987). Véanse también Cury (2005: 100 y ss.), Novoa (2005), Van Weezel (2011), Politoff (1997) y Mañalich (2014).

3. Desde la doctrina administrativa, entre otros, Aróstica (1987), Román (2008), Soto Kloss (1979/1980), Vergara (2004), Navarro (2005), Mendoza (2006), Alcalde (2011), Silva (2008) y Cordero Vega (2015).

4. Véase Silva Sánchez (2011: 138), quien da luces sobre la naturaleza de esta potestad: «el derecho administrativo sancionador es esencialmente el derecho del daño cumulativo o, también, del daño derivado de la repetición que exime de una valoración del hecho específico, requiriendo sólo una valoración acerca de cuál sería la trascendencia global de un género de conductas, si es que éste se estimara lícito. En otras palabras, la pregunta clave es: ¿qué pasaría si todos los intervinientes en este sector de actividad realizaran la conducta $\mathrm{X}$ cuando existe, además, una seria probabilidad de que muchos de ellos lo hagan, de ser estimada lícita?»

5. Sobre la configuración dogmática de la potestad en Chile, véase Rojas (2014).

6. En tal sentido, reconociendo el «aprovechamiento» del concepto de sanción por los particulares, Huergo: «No es raro, por otro lado, que los particulares intenten extender el concepto de sanción, pidiendo a los tribunales que reconozcan esa naturaleza a medidas que no la tienen. En el fondo late una paradoja: si ese régimen especial de las sanciones consiste, en último término, en un plus de garantías que tiene como finalidad proteger a los particulares frente a medidas de efectos especialmente graves para su esfera jurídica, no se entiende que las multas, como la resolución de un contrato o la revocación de una autorización» (1997: 186).

7. Da cuenta de la discusión jurídica (ideológica), Ferrada: «De este modo, la disputa sobre la potestad sancionadora pone en tensión las opciones de los autores por la mayor o menos protección de los intereses públicos o los derechos de los particulares, actuando estos últimos como contrapesos de los primeros» (2014: 241). 
La concepción de la luz roja es conocida entre nosotros. Se trata de un transplante [sic] del derecho penal al ámbito de las sanciones administrativas. En esta línea, la jurisprudencia constitucional y administrativa chilena ha establecido con claridad que tanto el castigo criminal como la sanción administrativa son ambos «manifestaciones del ius puniendi propio del Estado», exigiendo con ello un resguardo intensificado de los intereses privados (Montt, 2010: 18; el énfasis es nuestro).

Así las cosas, se ha buscado amparo bajo los principios y reglas garantistas que contempla el derecho penal. Esta situación histórica, pero más actual que nunca, se muestra en parte porque los órganos de la Administración del Estado parecen solamente conocer la sanción de multa para regular el sistema asignado (Romero, 2005: 539-554), pese a que en la generalidad de las agencias estatales se cuenta con más de una herramienta distinta para evitar llegar a la última y más grave atribución que poseen: multar.

Entre los factores que explican la extensa literatura jurídica sobre administrativo sancionador y derecho penal no sólo se encuentra la dominante doctrina del ius puniendi, sino además lo que se ha dado en denominar la «administrativización ${ }^{8}$ del derecho penal. Esto ha trastocado las fronteras, que alguna vez estuvieron delimitadas, entre el terreno penal y el campo administrativo. ${ }^{9}$ Esto ciertamente no contribuye a clarificar la discusión. Desde otro ángulo es sorprendente constatar el atomizado sistema «recursivo» que procura el ordenamiento jurídico chileno, donde convive el recurso de protección y la nulidad de derecho público para la salvaguarda de los derechos esenciales de las personas, con una excesiva gama de acciones judiciales para rebatir una decisión desfavorable de la administración. ${ }^{10}$ No obstante lo antes dicho, se intentará demostrar que en nuestro país apremia una solución legislativa que se

8. Silva Sánchez indica: «puede afirmarse que es una característica del derecho penal de las sociedades posindustriales el asumir, en amplia medida, tal forma de razonar, la de la lesividad global derivada de acumulaciones o repeticiones, tradicionalmente propia de lo administrativo. Es esto lo que se quiere indicar cuando se alude al proceso de «administrativización» en que, a nuestro juicio, se halla inmerso el derecho penal. Ello podría llevarse incluso más lejos: así, no sólo en cuanto a afirmar que el derecho penal asume el modo de razonar propio del derecho administrativo sancionador, sino que incluso a partir de ahí se convierte en un derecho de gestión ordinaria de grandes problemas sociales» (2011: 142-143).

9. Asimismo y mostrando a la «administrativización como patología», Feijóo sostiene: «El diagnóstico crítico también incide en la realidad que en muchas ocasiones el proceso de expansión provoca la yuxtaposición de las funciones preventivas del derecho penal y del derecho sancionador en general, pasando a ser muy difícil establecer diferenciaciones teóricas entre el derecho penal y otras ramas del ordenamiento jurídico, especialmente el derecho administrativo sancionador y el derecho policial de prevención de peligros, encontrándonos desde hace algún tiempo en un proceso progresivo de difuminación de fronteras.

Este proceso ha sido denominado - con más o menos acierto- como «administrativización del derecho penal», tratándose de un fenómeno característico del derecho penal moderno» (2007: 102-103).

10. Aróstica concluye que «el legislador ha preferido atomizar la justicia administrativa en un conjunto muy heterogéneo de acciones dispersas» (2008: 103). 
haga cargo de forma sistemática de los principios y reglas que ordenen el administrativo sancionador, así como su eventual reclamación ante a la justicia ordinaria. ${ }^{11}$ Prevenimos de antemano que se aludirá de manera indiferente a principios, reglas y garantías, sin efectuar profundización en su distingo. ${ }^{12}$ Un estudio de tales pretensiones ameritaría, al menos, una investigación por cuerda separada.

De cualquier modo, esperamos que lo que sigue sea un aporte al debate sobre un tema que suscita suma controversia en nuestro medio nacional. Desde nuestra mirada no resulta en alguno trivial intentar un esfuerzo por alcanzar una mejor comprensión de la materia que a continuación se expone.

\section{Presentación del problema: relación entre sanción penal y la sanción administrativa}

\section{Teorías de la diferencia cualitativa y de la diferencia cuantitativa}

Diversas teorías se han hecho cargo de intentar desentrañar la relación que tienen las infracciones del ámbito administrativo - que impone la Administración del Estado- ${ }^{13}$ con los delitos propiamente penales. Asimismo, es común que su configuración sea matizada con arreglo a una o más teorías diferenciadoras con base cuantitativa o cualitativa.

11. Véase Romero Seguel (2011) y Jara y Maturana (2009).

12. Sin perjuicio de que la Corte Suprema ha distinguido de cierta forma, en su sentencia rol 15.0152016, del 2 de agosto de 2016, entre principios, límites y garantías. En el considerando décimoquinto aclara: «Que la potestad sancionadora de la Administración admite un origen común con el derecho penal en el ius puniendi del Estado, por lo que le resultan aplicables los mismos principios, límites y garantías que en la Carta Fundamental se prescriben para el derecho punitivo, aunque ese traspaso haya de producirse con ciertos matices en consideración a la particular naturaleza de las contravenciones administrativas [...] Es por esto que se debe atender a la diferencia básica que existe entre la sanción administrativa y la penal, al momento de aplicar los principios del debido proceso, legalidad, tipicidad y culpabilidad». El matiz parece encontrarse justamente en la diversa finalidad que ambas ramas del ordenamiento jurídico poseen.

13. Respecto a la discusión sobre administración pública y administración del Estado, véase la decisión judicial, del 2 de octubre de 1986, rol sentencia del Tribunal Constitucional 39-1986, que señaló que en aplicación de la Ley Orgánica Constitucional de Bases Generales de la Administración del Estado debe entenderse que las expresiones son sinónimas y se utilizan en un sentido amplio y genérico. Esta sentencia es relevante porque aclaró una vieja discusión que se había suscitado bajo la Constitución de 1925 acerca de la distinción entre administración pública y administración del Estado. Todo lo anterior, en un contexto de dispersión orgánica y de denominación de los organismos administrativos chilenos (fiscales, semifiscales, autónomos, etcétera). Nuestra Constitución buscó uniformar esas denominaciones con la finalidad de dar un marco normativo común a los organismos que formaban parte de la administración del Estado. Para ahondar en esta dispersión orgánica, véase el Dictamen 64.792-1970 de la Contraloría General de la República. 
La primera teoría que buscó enseñar esta cuestión históricamente fue la teoría de la diferencia cualitativa. ${ }^{14}$ Así, esta teoría expresaba desde sus inicios que las infracciones administrativas estaban relegadas para aquellos hechos ilícitos de mera bagatela que no producían una aversión social suficiente para ser castigados con las herramientas del derecho penal. En otras palabras, el derecho penal quedaba reservado única y exclusivamente para los fuertes atentados que suponía el mayor instrumento de represión contra la libertad de los ciudadanos que conoce hoy el Estado de Derecho. En este sentido, Goldschimdt propuso que el delito era una conducta humana que lesiona o pone en riesgo bienes jurídicos dotados de protección y que por ello se opone a principios morales generalmente aceptados. En cambio, en su concepción la infracción administrativa importa una conducta que entra en contradicción exclusivamente contra los intereses de la Administración (Román, 2008: 121). ${ }^{15}$

Con el paso de los años, algunas críticas surgieron a raíz del planteamiento recién esbozado. Así, un connotado penalista alemán aclara: «El derecho penal positivo se resiste a una delimitación cualitativa tajante de infracción penal y contravención. No cabe determinar diferencias cualitativas entre infracción penal y contravención de claridad contrastable en la práctica» (Jakobs, 1997: 67) ${ }^{16}$ De este modo, la distinción fundamental entre el delito y la contravención para la mayoría se enmarcaría por una diferencia de carácter cuantitativo. ${ }^{17}$ En Chile, Cury (1979: 89) se mostró enfático al postular que no resultaba aceptable una teoría que pretendiera encontrar el distingo de ambas ramas, en el supuesto de que en una de ellas no sería necesario el componente de la culpabilidad.

Dentro del mismo marco conceptual, comenzaría a imponerse la mencionada teoría de la diferencia cuantitativa, ${ }^{18}$ en que la medida (gravedad) de la sanción ${ }^{19}$ permite

14. En Chile, así lo sostuvo Labatut (1968: 217) y también Novoa (2005: 205).

15. Cousiño (1975: 24) se inclinaba por semejante diferenciación basado en que la culpabilidad era un componente del delito, mas no de la infracción administrativa.

16. Para probar tal aserto, el autor cita el delito de circulación en embriaguez del $₫ 316 \mathrm{StGB}$ con infracción penal; y el $\$ 24$ StVG como contravención. Una postura similar parece encontrarse en Roxin, quien señala: «De ello se deriva que no existe una diferencia cualitativa para una precisa separación entre hechos punibles y contravenciones [...] El juicio de desvalor ético en las contravenciones sólo es menor que el de los hechos punibles en la medida en que disminuye su peligrosidad social» (1997: 72).

17. En la doctrina española, Cerezo expresa, siguiendo a Welzel, que «desde el núcleo central del derecho penal hasta las últimas faltas penales o infracciones administrativas discurre una línea continua de un ilícito, materia que se va atenuando, pero que no llega a desaparecer nunca del todo» (1981: 49).

18. En este sentido, véase Alcalde (2009: 795 y ss.). Así se inclinaba expresamente Garrido: «Sólo cuantitativamente puede diferenciarse la infracción administrativa y la penal; la primera tiene un menor injusto que la segunda, pero la naturaleza de ambas es análoga, lo que obligaría a someterlas —en lo posible- a principios limitativos y garantistas semejantes» (2001: 85-86).

19. «Para afirmar aquello sostienen, en primer lugar, que entre la sanción administrativa y la pena existe una identidad ontológica, existiendo entre ellas tan sólo diferencias de grado o intensidad, y, en 
verificar si estamos en presencia de un hecho punible o una contravención administrativa. ${ }^{20}$ De esta forma, los delitos penales poseen consecuencias más perniciosas para sus eventuales infractores, mientras que la contravención administrativa reviste una sanción para sus desobedientes de menor intensidad. El lector podrá imaginar de inmediato el problema que tal afirmación supone: algunas infracciones administrativas en la legislación chilena son castigadas con graves sanciones, verbigracia las cuantiosas multas. ${ }^{21}$ Pese a las intensas sanciones que puede imponer la Administración de una rápida lectura a los principales textos legales, sus fines de regulación no se logran observar. ${ }^{22}$

\section{Algunas consideraciones acerca de la sanción administrativa en la doctrina chilena}

Parece acertado principiar esta propuesta con algunas concisas reflexiones sobre el contenido de la sanción administrativa para nuestros autores, independiente de las diversas versiones y teorías que defienden. Como se quiera, en nuestro país el análisis comienza generalmente por el artículo $2 \mathrm{O}^{23}$ del Código Penal. ${ }^{24} \mathrm{El}$ precepto ha

segundo lugar, que tanto el derecho penal como el 'penal administrativo' - como ellos llaman al derecho administrativo sancionador- son manifestación de un mismo y único ius puniendi del Estado» (Román, 2009: 190).

20. En nuestro país, alguna autorizada doctrina pretende sostener que la potestad administrativa sancionatoria revestiría - todavía - un carácter abiertamente inconstitucional. Sobre esto ha vuelto recientemente Soto Kloss (2014: 39 y ss.). Aróstica apunta: «no cabe sino concluir que, si sancionar supone juzgar tal poder, le está vedado a la Administración, pues le pertenece con exclusividad a los jueces» (1987: 72).

21. La regulación sectorial chilena es particularmente reflejo de ello. Por ejemplo, en el caso de las multas que puede aplicar la Superintendencia de Electricidad y Combustibles de hasta 10.000 Unidades Tributarias Anuales, según la Ley 19.613, en especial el artículo 16 letra a).

22. Por ejemplo, las facultades de la Superintendencia de Bancos e Instituciones Financieras (SBIF) contenidas en el artículo 2 del Decreto con Fuerza de Ley núm. 3 de 1997 del Ministerio de Hacienda; la Ley 20.417, que crea la Superintendencia de Medio Ambiente, y que modifica la Ley 19.300; y las facultades de la Superintendencia de Valores y Seguros (SVS) en el Decreto Ley 3.538, del año 1980, en especial su artículo 3. Todas redundan en las habilitaciones para fiscalizar, sin expresión de sus objetivos para reglar el sistema.

23. El precepto define: «No se reputan penas, la restricción o privación de libertad de los detenidos o sometidos a prisión preventiva u otras medidas cautelares personales, la separación de los empleos públicos acordada por las autoridades en uso de sus atribuciones o por el tribunal durante el proceso o para instruirlo, ni las multas y demás correcciones que los superiores impongan a sus subordinados y administrados en uso de su jurisdicción disciplinal o atribuciones gubernativas».

24. Guzmán Dalbora apunta que «varias de las privaciones que se enuncian aquí eran formalmente penas hasta las postrimerías del siglo XVIII. Esto vale en especial respecto de las sanciones disciplinarias y gubernamentales, atendida la concentración de poderes públicos bajo la monarquía absoluta, cuando 
presentado diversas interpretaciones. Algunos han comprendido que la disposición despliega un alcance netamente negativo, ${ }^{25} \mathrm{o}$ sea, define qué es lo que no debe comprenderse como pena. En dicho sentido se puede extraer del mismo lo que no se entenderá como pena para efectos del mismo código, no explicitando si la sanción administrativa tiene o no realmente el aludido carácter penal. Por ello, común es distinguir entre sanción gubernativa y disciplinaria (Cury, 2005: 87). Al esbozar una definición de manera plausible es posible afirmar que sanciones disciplinarias ${ }^{26}$ podrían conceptualizarse como aquellas que se imponen a los funcionarios públicos por orden del superior jerárquico, en uso de atribución legal al efecto, con fundamento en el incumplimiento de deberes propios del cargo. ${ }^{27}$ Por su parte, en cambio, la sanción administrativa (o gubernativa) tiene por objeto la protección de la intangibilidad del ordenamiento jurídico (Bermúdez, 2012: 115) o bien la protección de un sistema de regulación sectorial (Cordero, 2014: 161-163). Mas nunca estas sanciones buscan ejercitar el «derecho subjetivo del Estado a castigar: ius puniendi». En una línea semejante de pensamiento, y a propósito del sistema de penas, se ha propuesto que el verdadero sentido y alcance del artículo 20 del Código Penal delimitaría el asunto únicamente desde una perspectiva formal. En ese sentido, la oración «no se reputan penas» indaga exclusivamente relevar de los efectos penales de la condena a las medidas que cita tal artículo (Guzmán Dalbora, 2008: 102-103) ${ }^{28}$ sin perjuicio de que, aunque no nazcan las derivaciones del carácter de pena, se hallan sujetas al principio de legalidad (Guzmán Dalbora, 2008: 103).29

no existía una separación neta entre los aparatos penal y administrativo de sanciones, confusión que llegó hasta el extremo de emplear como pena el servicio en cuerpos militares» (2008: 101-103).

25. Véase Couso y Hernández (2011: 444-450). Hernández (2014: 2 y ss.) hace presente que el derecho administrativo sancionatorio «al no poseer principios ni reglas propias debe recurrir a los principios del derecho penal para la aplicación de ius puniendi».

26. De dilatado tratamiento doctrinal por Silva (1993). Asimismo, Pantoja (2000).

27. Definición de elaboración propia, siguiendo a Couso y Hernández (2011: 445).

28. Quien concluye que: «Quien sufre alguno de ellos no lo verá inscrito en el Registro General de Condenas ni, por ende, se le contará en el número de los reincidentes si decide delinquir alguna vez; hasta ese momento gozará jurídicamente de una conducta irreprochable».

29. Afirma que se encontrarían también protegidas bajo el principio de culpabilidad penal. Cuestión que, como se puede observar, alguna reciente jurisprudencia no comparte del todo para las sanciones administrativas, por ejemplo, la sentencia de la Corte Suprema en el caso Aguas Araucanía S.A. con Comisión Nacional del Medio Ambiente, rol 24.233-2014, en que la Corte asimila el estándar de culpa infraccional del derecho civil para las sanciones administrativas. Sobre el principio de culpabilidad en el derecho administrativo sancionador, se ha dicho: «el derecho administrativo sancionador se inspira, entre otros, en el principio de la culpabilidad, en virtud del cual sólo cabe imponer una sanción a quien pueda dirigírsele un reproche personal por la ejecución de la conducta, quedando excluida la posibilidad de aplicar medidas punitivas frente a un hecho que sólo aparenta ser el resultado de una acción u omisión, sin verificar previamente la culpabilidad personal, como ocurre en la llamada responsabilidad 
Desde la vertiente administrativa del derecho (Bermúdez, 2014: 3-15) ${ }^{30}$ se ha distinguido ${ }^{31}$ entre una noción amplia y una restrictiva de sanción. Precisamente, la sanción administrativa en sentido amplio es concebida como toda aquella retribución negativa ${ }^{32}$ que provenga de la Administración producto de alguna acción u omisión cometida por particulares, que suponga una vulneración al ordenamiento jurídico. Stricto sensu, la sanción administrativa es aquella que ha sido «tipificada en ese específico sentido por el ordenamiento jurídico y que se emplea, opera o se atribuye por la Administración, exclusivamente cuando se ha cometido una infracción administrativa» (Bermúdez, 2013: 330).

Desde una visión análoga, arguyendo — sin necesidad de recurrir a la teoría dominante del ius puniendi- mínimas garantías para los administrados, se ha concluido:

Las sanciones son típicamente un acto de gravamen, y si bien pueden existir discrepancias de los alcances específicos de sus contenidos, hay acuerdo de que éstas existen cuando hay un mal infringido por la Administración a un administrado como consecuencia de una conducta ilegal. Este mal (inactivo de la sanción) consistirá siempre en la privación de un bien o de un derecho, o en la imposición de una obligación de pago de una multa. Esta circunstancia explica, precisamente, la existencia de un conjunto de garantías básicas (Cordero Vega, 2015: 496).

Lo referido en cita consuma al mismo tiempo el principio general de la debida fundamentación de todo acto administrativo. ${ }^{33}$ Así, no resulta suficiente la simple

objetiva», Dictamen 31.239 de 2005 de la Contraloría General de la República. Crítico ante tal pronunciamiento es Román (2008: 135-136).

30. El autor identifica los siguientes elementos comunes para estar frente a una sanción administrativa: i) que sean un acto decisorio desfavorable, ii) emitido por un sujeto dotado de potestades públicas administrativas sobre otro, quien se encuentra sujeto a una regulación determinada, iii) que la medida esté antecedida de un procedimiento previo, y iv) que su finalidad sea la represión de una contravención normativa, en atención a la protección del bien jurídico a que debe atender el organismo sancionador, utilizando como determinante el criterio del bien jurídico protegido por la norma de sanción.

31. En su premonitorio trabajo, y una vez analizada la potestad sancionatoria del Estado desde el punto de vista constitucional, Rodríguez Collao (1987: 123) logra sostener la identidad ontológica entre ambas clases de sanciones. Al mismo tiempo, puede llegar a la distinción entre un concepto genérico de pena, uno intermedio y otro restringido. El primero incluye todo tipo de castigo a raíz de la ejecución de una conducta indebida. El segundo comprende toda sanción impuesta por los órganos del Estado. Y el tercero, utilizado sólo por el Código Penal, considera las sanciones que prescribe.

32. Sobre la legitimación de la pena fundamentada derechamente en una retribución por culpabilidad del infractor a su imputable acción (u omisión) criminal, véase Kindhauser y Mañalich (2011: 22-25). Recientemente, y defendiendo la tesis de Beling sobre una concepción retributiva de la pena, puede verse Mañalich (2015).

33. En relación a la motivación del acto administrativo en España, Rodríguez (2011: 211-233) distingue las condiciones para el ejercicio de la potestad discrecional: i) ajuste a la ley (no pueden contradecir a la ley), ii) ajuste a la finalidad de la potestad, iii) ajuste a los criterios explícitos o implícitos de la ley, 
mención de normas legales para entender satisfecho este requerimiento, ni tampoco la simple mención de hechos que carecen de nexo de causalidad con el reproche que se realiza. Es más, el acto administrativo de cargos que supone la futura aplicación de una sanción debe ser especialmente motivado.

De cualquier modo hoy, tanto la doctrina como la jurisprudencia mayoritaria, han reconocido que la potestad sancionadora de la Administración se enmarca dentro de un tronco común mayor, en el así denominado ius puniendi de monopolio estatal (Vergara, 2004). ${ }^{34}$ En otros términos, tanto la potestad sancionadora de la administración como el derecho penal coexistirían bajo un supra concepto metanormativo de ius puniendi. ${ }^{35}$ La raíz de esta tesis puede encontrarse en Chile ${ }^{36}$ en la célebre sentencia Tribunal Constitucional rol 244-1996, en el conocidísimo caso de la Ley de Caza, que en su considerando noveno explicitó: «Que, los principios inspiradores del orden penal contemplados en la Constitución Política de la República han de aplicarse, por regla general, al derecho administrativo sancionador, puesto que ambos son manifestaciones del ius puniendi propio del Estado».

Como se verá, este fallo fue tomado de la jurisprudencia española. ${ }^{37}$ Aquel pronunciamiento obedece, además, a un contexto histórico particular de regreso a la democracia en ese país (Huergo, 1997: 28), ${ }^{38}$ en circunstancias que la Carta Fundamental

iv) ajuste a los principios generales. Para el caso chileno, véase Aróstica (1986) Fermandois y Baraona (2003).

34. Sobre la regulación sectorial de la Superintendencia de Electricidad y Combustible (SEC), Vergara ha señalado: «El ius puniendi del Estado, ya sea en su manifestación penal o administrativa, dada la evidente naturaleza común, en su ejercicio debe respetar los mismos principios de legalidad y tipicidad y sus derivados (culpabilidad y non bis in ídem). En otras palabras, aunque exista una dualidad de sistemas represivos del Estado, en ambos casos, por su unidad material, aunque el procedimiento sea distinto, se han de respetar estos principios de fondo: es el mismo ius puniendi del Estado. Entonces, los principios conocidos generalmente como del derecho penal, hay que considerarlos como principios generales del derecho sancionador, y tales principios tradicionales del derecho penal se aplican a la esfera sancionatoria administrativa».

35. Segura (2014: 165) señala sobre este metaconcepto: «Por lo demás, no se puede obviar que esta tesis, parte de un análisis metanormativo que busca como efecto primordial identificar las infracciones y delitos por un lado, y sanciones y penas por otro, para, con posterioridad, proyectar dicha igualdad ontológica en el régimen jurídico positivo».

36. En España, puede encontrarse el día 8 de junio del año 1981, cuando el Tribunal Constitucional español apreciaba que «los principios inspiradores del orden penal son de aplicación con ciertos matices, al derecho administrativo sancionador, dado que ambos son manifestaciones del ordenamiento punitivo del Estado tal y como refleja la propia Constitución».

37. Sentencia TC Español 18/1981, de 8 de junio, BOE núm. 143, de 16 de junio de 1981. Así también, el Tribunal Supremo Español, Sentencia de la Sala Cuarta de 29 de septiembre, 4 y 10 de noviembre de 1980 .

38. Así da cuenta el autor, quien expresa: «Con la tesis al uso sobre las sanciones se reacciona frente a una época (el franquismo) en la que la ley sólo rodeaba de garantías a la imposición de la pena, dejando 
española posee texto expreso al respecto. ${ }^{39}$ Uno de los problemas está, justamente, en que nuestro sistema carece de tal precepto constitucional, al menos redactado en esos términos. No obstante, la tesis sobre la que reflexionamos ha encontrado asidero tanto en la Corte Suprema ${ }^{40}$ de Chile, como en la Contraloría General de la República. ${ }^{41}$

\section{La pretendida unidad del ius puniendi estatal}

\section{El alcance del concepto de ius puniendi}

En este contexto, más de alguna crítica se ha formulado ${ }^{42}$ a la tesis del ius puniendi unitario del Estado. Para esta doctrina, ambas ramas del ordenamiento jurídico son manifestaciones del derecho del Estado a castigar. Castigar solo aquellas conductas que se han considerado, por la sociedad, acreedoras del mayor reproche ético-social. Por ello, el derecho penal, a la vez, que permite la mayor intromisión en la esfera de libertad ${ }^{43}$ del ciudadano, concede principios y reglas de corte garantista -al menosen un verdadero Estado de Derecho.

Pero, ¿qué es el ius puniendi del Estado? Lo cierto es que sobre esta inquietud poco discurren los pronunciamientos judiciales, así como los defensores de esta tesis. Por su profundidad, implausible es en estas líneas pretender conceptualizar esta cuestión. Detengámonos en recordar que: «La imposición de la pena, concebida como un mal que se inflige al delincuente, ha dado origen al problema de encontrar una justifica-

al ciudadano huérfano de protección frente a las sanciones administrativas, lo que se justificaba precisamente por su heterogeneidad». Vale la pena recordar que el «franquismo» tuvo lugar desde el año 1936 hasta la muerte del gobernador de facto en 1975.

39. «Artículo 25.1. Nadie puede ser condenado o sancionado por acciones u omisiones que en el momento de producirse no constituyan delito, falta o infracción administrativa, según la legislación vigente en aquel momento.»

40. Véase, entre otros, la sentencia de la Corte Suprema del 10 de septiembre de 2009, en la causa rol 3357-09, considerando octavo.

41. Recogidos fundamentalmente en el Dictamen 14.571 de 2005, y en Dictamen 63.697 de 2011.

42. Cf. Mañalich (2014: 545). Crítico a su vez en relación al argumento del ius puniendi, Nieto plantea: «El enorme éxito del tal postura - elevada ya a la categoría de dogma incuestionable - se debe en parte a razones ideológicas, a que así se atempera el rechazo que suelen producir las actuaciones sancionadoras de la Administración, de corte autoritario, y, en parte, a razones técnicas, en cuanto a que gracias a este entronque con el derecho público estatal se proporciona al derecho administrativo sancionador un soporte conceptual y operativo del que antes carecía» (2005: 22). En el mismo sentido, Peman (2000: 27). Ambos citados a su vez por Román (2009: 191).

43. El otrora artículo 169 del Código Sanitario, actualmente derogado, consentía el apremio de arresto por la autoridad administrativa, en circunstancias que la Constitución proscribe la privación de libertad como sanción administrativa. Sin embargo, éste era un caso permitido. La sentencia del Tribunal Constitucional en la causa rol 1518, de octubre de 2010, lo declaró inaplicable, porque viola el debido proceso y es desproporcionado a su objetivo. 
ción filosófica al derecho que el Estado (o la sociedad) se atribuye a sí mismo para imponer castigos a sus miembros: el llamado ius puniendi o derecho de castigar» (Etcheberry 1999: 30). ${ }^{44}$

En efecto, el ius puniendi ha sido caracterizado como una especie de derecho subjetivo a castigar de prerrogativa exclusiva del Estado (Matus, Politoff y Ramírez, 2004: 55). ${ }^{45}$ Sin embargo, latente se encuentra la inconsistencia que supone el argumentar que al administrado le asisten garantías - sustantivas y procedimentales - en aplicación de la potestad administrativa sancionadora, por pertenecer ella a este ius puniendi. La relevancia de esta distinción entre potestad y derecho subjetivo permite atestiguar esta aseveración. De este modo, la potestad debe ser comprendida como «esfera cualquiera del poder soberano del Estado que por su carácter ordenador de la sociedad se le impone al individuo en mayor o menor intensidad» (Rojas, 2014: 16; el énfasis es nuestro). A su turno, el derecho subjetivo «sería el propio o específico del poder individual - un derecho relativo al sujeto- que corresponde a la esfera de su libertad individual» (Rojas, 2014: 17).

En este orden de ideas, la tesis del ius puniendi se muestra insuficiente para explicar el asunto, ya que lo que despliega ciertamente la Administración es una potestad (no el derecho subjetivo de castigar) de ordenar un sector de la sociedad por considerarlo especialmente relevante (aguas, mercado eléctrico, medio ambiente, sanitario, etcétera). Ahora bien, objetar que la potestad sancionadora de la Administración no descansa en el ius puniendi, no equivale a sostener la renuncia de garantías tanto sustantivas como adjetivas dentro del procedimiento administrativo sancionador. A mayor abundamiento, a pesar de ser cuestiones que desde algún punto de vista pueden presentarse similares, son en definitivas disímiles, dado que sus objetivos dentro del sistema jurídico las convierten en distintas, ${ }^{46}$ puesto que, como frecuentemente se muestra, el derecho administrativo sancionador es una rama autónoma del ordenamiento jurídico que tiene su «anclaje» en el derecho úblico, específicamente en el administrativo (Román, 2009: 191). Lo anterior pone de relieve lo que venimos

44. Aún más crítico es Zaffaroni: «La pretensión de taxatividad fue fundada en un supuesto ius puniendi o derecho subjetivo de punir, cuyo titular sería el Estado. Se ha visto que este ius puniendi no existe, sino que se trata de una potentia puniendi necesitada de contención y reducción» (2002: 111).

45. Los mismos autores señalan al respecto: «facultad que se conoce bajo la denominación de derecho penal subjetivo, o ius puniendi o poder punitivo». En similar sentido, Cury (2008: 37-44).

46. Con razón el Tribunal Constitucional, en el caso «Eléctricas», sentencia rol 480-2006, señaló en su considerando decimotercero: «Que afirmar que una determinada materia está regida por el principio de legalidad no equivale necesariamente a excluir que la potestad reglamentaria de ejecución pueda, dentro de los márgenes constitucionales, normar esa materia». Del mismo modo, el Tribunal Constitucional español, en sentencia 61/1990, señaló: «en supuestos de remisión de la norma legal a normas reglamentarias, si en aquella quedan suficientemente determinados los elementos esenciales de la conducta antijurídica... y la naturaleza y límites de las sanciones a imponer». 
señalando con respecto a los fines o diversos objetivos de cada rama del derecho. El administrativo sancionatorio tiene por función cardinal la satisfacción del interés general (público) por sobre el particular, en un determinado sector de la sociedad. Y es solo en segundo lugar que debe dotar de garantías al eventual perseguido. ${ }^{47}$

Desde España, la clásica obra de Nieto demostró que describir a una y otra rama como exposiciones de un metaconcepto normativo superior (Nieto, 2005: 161) -ius puniendi del Estado- resulta por diversas razones debatible. La evidencia de tal crítica se encuentra en defender la sustantividad para el derecho administrativo sancionador y su necesaria desvinculación del derecho penal. Y con justa razón es impreciso sostener que la eventual identidad ontológica metanormativa asegure que el derecho tenga que otorgarle correlativa identidad en el régimen para su tratamiento. En suma, dice Nieto, no resuelve el problema central y originario del derecho aplicable para esta constelación de casos (Nieto, 2005: 161-162)..$^{48}$ Por lo demás, esta identidad podría bien abordarse desde la filosofía, mas no por el operador jurídico, ${ }^{49}$ ya que es una cuestión que al parecer escapa a su competencia. En otras palabras, el sustentar que estos dos tipos normativos la «infracción administrativa» y el «delito penal» poseen una identidad en el mundo real (material) similar, no autoriza necesariamente a dispensarles equivalente régimen jurídico. En similar sentido, en Chile se han alzado voces que reclaman genuinamente - la legítima autonomía del administrativo sancionador. No obstante —señalan dichos autores - que por la carencia de desarrollo dogmático en el derecho administrativo sancionador deben aprehenderse en préstamo los principios y reglas, largamente, ya asentados del derecho penal (Román, 2008: 137).50 Desde luego que el argumento anterior debe compartirse. Nadie en su sano juicio permitiría contradecir sesudamente que a los presuntos infractores no se les concediera garantía alguna. Una aseveración de estas características permitiría confirmar la caracterización - de voces autorizadas - de identificar al derecho administrativo sancionador como un antiguo derecho prebeccariano (Mendoza, 2004), ${ }^{51}$ abstraído en el antiguo Estado de policía.

47. Véase en este sentido Nieto (2005: 26-27) y De Palma (1996: 39-40), citados a su vez por Román (2009: 192).

48. Quien en sus términos expresa: «que la pretendida y harto magnificada identidad ontológica (entendida como una identidad de fenómenos reales no normativos, o más exactamente, todavía, prenormativos): a) es jurídicamente casi irrelevante dado que la hipotética identidad ontológica meta normativa no garantiza correlativa identidad de regímenes legales; b) es incongruente con la tesis de unidad superior; c) además es inútil porque no resuelve el problema central y originario del derecho aplicable».

49. De acuerdo al Diccionario de la lengua española, la ontología es la «Parte de la metafísica que trata del ser en general y de sus propiedades trascendentales».

50. Defendiendo un regreso a lo administrativo Zúñiga (2015: 414).

51. En dirección similar, García De Enterría y Fernández sostenían que «frente al afinamiento de los criterios y de los métodos del derecho penal, el derecho sancionatorio administrativo ha aparecido durante mucho tiempo como un derecho represivo primario y arcaico [...] Sin hipérbole puede decirse que 
Pues bien, la correspondencia de principios y reglas penales en su justa medida para el procedimiento administrativo sancionador es la motivación de estas líneas. Dado que la potestad de sanción administrativa es una herramienta para regular un sistema social y no parte del derecho subjetivo del Estado a castigar, lo que reflexionemos como «justo» en este caso será, por supuesto, controvertible. Todavía más, ningún ciudadano pretenderá apartarse de la «protección» de las garantías que ofrece el derecho penal a los eventuales infractores de la potestad sancionadora de la Administración. El problema es que una consideración racional de los fines (teleológica) ${ }^{52}$ de cada rama del ordenamiento jurídico consiente oponerse a una extrapolación completa de un sistema (penal) a otro (derecho administrativo sancionador), que tiene distintos objetivos. Así, se ha expuesto que la aplicación matizada de la estructura penal (principios, límites y garantías) al administrativo sancionatorio, busca evitar llevarnos a desnaturalizar la potestad que tiene la Administración ${ }^{53}$ para sancionar (mejor dicho: regular). Al mismo tiempo en nuestro país esta misma consideración racional permite otorgar a los ciudadanos garantías similares - para evitar el (eventual) abuso de la Administración- y no arrancar de raíz el contenido propio que tiene el derecho administrativo sancionador. Lo anterior es solamente sostenible en la medida que en Chile todavía perdure un vacío que contemple una regulación sistemática e integral de las sanciones administrativas como un instrumento más de regulación.

Por ello, el punto clave parece estar en que una alusión directa a los fines de estas diversas ramas del derecho permite reconstruir o clarificar el presente escenario; esto quiere decir que los fines que tiene una zona de regulación se deben tomar en cuenta para resolver sobre la sensatez de aplicar garantías y principios del orden penal al derecho administrativo sancionador. Si se comparte lo precedente, capital es la inclusión explícita de los fines u objetivos en los textos legales que ordenan las funciones de las agencias estatales.

el derecho administrativo sancionador es un derecho represivo prebeccariano» (2002: 157). En contra está Cordero Vega: «Con ello el sistema prebeccariano en el que la Administración podía aplicar sanciones administrativas de plano y sin resguardar las garantías y derechos de los ciudadanos, está hoy constitucionalmente proscrito. En la actualidad ocurre lo opuesto: no sólo es imprescindible la tramitación de un procedimiento para la imposición de sanciones administrativas, sino que en esos procedimientos rigen variadas garantías, especialmente los derechos de defensa y otros derechos formales caracterizados por su elevado nivel garantista» (2010: 248).

52. Así también, Oksenberg y Flores: «Una correcta interpretación de las facultades sancionatorias de la Administración debe realizarse teleológicamente a partir de los bienes jurídicos que se busca proteger por las disposiciones sectoriales» (2009: 180).

53. De misma idea está en la sentencia de la Corte Suprema, rol 15.015-2016, considerandos decimocuarto y decimoquinto. 


\section{El discutible origen de la potestad sancionadora administrativa en el ius puniendi}

Cada vez con mayor intensidad se tiende a expresar lo insatisfactorio que resulta concentrar la discusión en la tesis de la unidad del ius puniendi estatal. ${ }^{54}$ Si uno considera algunas de estas cuestiones puede vislumbrar que los fines del derecho penal y del derecho administrativo sancionador son palmariamente distintos. En consecuencia, divergentes son sus regulaciones e igualmente deben ser diferentes las garantías y reglas que deben dominar tal procedimiento. E insistimos, el regulado puede guardar calma: a los administrados les asisten suficientes garantías. Pero son garantías que deben atender al fin del sistema regulado en que se desenvuelve la potestad administrativa. En definitiva, como correctamente exponen algunos autores, es por "premura dogmática ${ }^{55}$ que deben tomarse prestados los principios ya asentados del derecho penal. Sin embargo, creemos no por integrar un origen común con el ius puniendi estatal.

Como expusimos precedentemente, se han alzado voces críticas de la supuesta unidad del ius puniendi estatal, aunque sin alcanzar a alterar lo sostenido por la jurisprudencia nacional. Este escenario es expresivo de la falta de impacto de tales planteamientos en nuestra jurisprudencia, al momento de emitir sus decisiones. No obstante, la reflexión es potente, por cuanto Mañalich (2014: 545) $)^{56}$ ha probado de manera contundente lo insatisfactorio que resulta defender que la conexión entre el

54. Cf. Bermúdez que, sin perjuicio de sostener el ius puniendi único, correctamente identifica que: «En una exploración de la doctrina del ius puniendi unitario podríamos reafirmar la pretendida identidad ontológica y consecuente aplicabilidad en bloque y sin más de los principios penales al ámbito administrativo sancionador. Sin embargo [...] tales principios extraídos desde el derecho penal, en la vertiente administrativa cobran una vigencia diversa, más propia del objeto de su regulación» (2012: 334; el énfasis es nuestro).

55. Román (2008 138) postula la autonomía constitucional del administrativo sancionador. Al efecto, establece que por premura dogmática es menester «tomar prestados» los principios del orden penal que cuentan con consistencia y aplicarlos como pauta, mas nunca por una subordinación entre ambas ramas. Novoa (2005: 39), sin perjuicio de plantear que derecho penal y administrativo son diversos, propone que se rodeen con similares garantías a los administrados en los procedimientos incoados en su contra. Véase también Zúñiga (2015: 414).

56. Mañalich señala además: «El recurso al eslogan de la unidad del ius puniendi estatal es especialmente lamentable, en tanto supone una vulgarización del concepto técnico de pretensión punitiva, por la vía de confundirlo con la designación del entramado de reglas de competencia que especifican las condiciones de ejercicio de las muy diversas potestades públicas involucradas en la eventual materialización de alguna concreta pretensión punitiva fundamentada en una determinada instancia de quebrantamiento (imputable) del derecho. Pero siendo ésta nuestra situación 'histórico-espiritual', aquí se sostendrá - en contra del lugar común recién identificado- que la aplicabilidad del principio ne bis in ídem, tratándose de una posible concurrencia del ejercicio de potestades persecutorias y sancionatorias de índole penal y de índole administrativa, no depende de si la diferencia entre éstas se entiende como una diferencia cualitativa o cuantitativa». 
derecho penal y el administrativo sancionatorio se encontraría en la teoría de la diferencia cuantitativa, a la que subyace la tesis que favorece la unidad del ius puniendi. Para el citado autor, el recurso a la noción de unidad de ius puniendi del Estado se constituye como una banalización del concepto técnico de pretensión punitiva de monopolio estatal. Con observancia de ese raciocinio, se confunde entonces el conjunto de reglas que otorga competencia a una potestad pública sancionatoria, para satisfacer su respectiva pretensión punitiva por el quebrantamiento imputable de una norma, que a al mismo tiempo persigue atribuir responsabilidad ya sea administrativa o sea penal. En este punto lo que ocurre es que se pasa por alto que la divergencia es estrictamente relativa a la diferente configuración institucional de una pena y una sanción administrativa. Lo anterior en tanto consecuencias jurídicas de una y otra especie de quebrantamiento del derecho, respectivamente (Mañalich, 2014: 545, nota 6).

Dentro de esta misma materia y en relación a la eventual violación al ne bis in ídem (Ossandón, 2015: 87-110) que puede existir en la especie, se pronuncia García Cavero, quien ha señalado una alternativa de interpretación para la vinculación entre sanción penal y sanción administrativa (2016: 21-33). A la interrogante relativa a la eventual existencia de ne bis in ídem, García Cavero ha expresado que el encargado de dirimir tal cuestión es el adjudicador, vale decir, el juez, fundamentalmente con base en el juicio de necesidad (de la sanción) que debe resolver para el caso particular. De igual modo sería imposible determinar si la imposición conjunta de pena y sanción administrativa constituye una sobrerreacción sancionatoria, sin mantener claridad de la relación funcional existente entre el derecho penal y el administrativo sancionatorio. Lo anterior es dado que uno y otro ilícito responden a un hecho básico: la defraudación de una expectativa social (Jakobs, 2015: 75 y ss.). ${ }^{57}$ Así, enuncia que la diferencia cualitativa se manifiesta en que la infracción administrativa se determina en un plano cognitivo al tratar al administrado como ser sensible que debe ser conminado a actuar correctamente en el sector administrativamente regulado. En cambio, la amenaza penal principia de la idea de un ciudadano, comprendido como un ser inteligible cuyo comportamiento debe ser merecedor de una pretensión de validez. En síntesis, García Cavero estima que el principio ne bis in ídem material en concurrencia de la pena y de una sanción administrativa es una expresión del juicio de necesidad. Su naturaleza constitucional se la debe al principio de proporcionalidad y no al de legalidad; la determinación del juicio de necesidad de sanción debe responder a cada caso concreto. En otras palabras, estamos frente a un caso de proporcionalidad concreta y no abstracta. Lo interesante es que el argumento de García Cavero permite aseverar en cierto sentido lo que aquí se viene defendiendo, dado que una correcta identificación de los fines u objetivos de cada rama del derecho asiente discernir entre los principios, reglas y límites que dispensar a cada una de ellas. Es

57. Citado a su vez por García Cavero (2016: 28, nota 22). 
del caso subrayar que al fijar el sentido y alcance en el juicio de necesidad para el principio de ne bis in ídem material - que ocupa su estudio- no se intenta establecer una primacía de la sanción penal por sobre la sanción administrativa. Es más, esta regla puede encontrar una excepción según puede observarse en la siguiente hipótesis: el caso de que el injusto penal sea especialmente débil y la sanción administrativa sumamente intensa. Asimismo, en la tentativa de un delito de peligro concreto que constituye, simultáneamente, una infracción administrativa que es castigada con multas millonarias (García Cavero, 2016: 31).$^{58}$ La relación de necesidad se invierte, por lo que bastará con imponer la sanción administrativa, que es en esta hipótesis sustancialmente aguda.

\section{La Administración pública posee herramientas previas a la imposición de la multa. Acerca de potestades prima ratio y regulación responsiva}

\section{El principio de necesidad y las potestades ultima ratio}

Desde Chile se ha planteado que la potestad administrativa de sanción debe encontrar su límite en las variadas herramientas que ostenta para evaluar la sanción de una conducta. De esta forma, la Administración del Estado cuenta con herramientas de regulación que circulan desde los llamados de atención (warning) pasando por amonestaciones, programas de cumplimiento, ${ }^{59}$ autodenuncia,${ }^{60}$ paralización de faenas, clausuras de establecimiento, entre otras. Este orden de sanciones suele terminar en una de las más graves: la multa.

$\mathrm{Al}$ efecto, e inserto en la literatura chilena administrativista, Arancibia esbozó una tesis que pretende encontrar en las diversas herramientas de la potestad administrativa la aplicación previa de otros mecanismos antes que la sanción de multa derechamente (Arancibia, 2014: 129-147). En relación con este particular, expresa que: «en virtud del principio de necesidad, la sanción administrativa es una potestad de ultima ratio (Prittwitz, 2000: 427-446) ${ }^{61}$ que sólo es necesaria y, por ende, justa en caso de in-

58. Véase en Chile, por ejemplo, las cuantiosas multas existentes en supuestos de infracción al mercado financiero regulado que puede imponer la Superintendencia de Valores y Seguros, de acuerdo a la Ley 18.045 del 22 de octubre de 1981. En este sentido, véase Londoño (2014: 147-167).

59. Hoy se observa en el programa de cumplimiento de la normativa ambiental y el plan de reparación del daño ambiental regido por los artículos 42 y 43 de la Ley 20.417, Orgánica Constitucional de la Superintendencia del Medio Ambiente. Dice Soto: «En la revisión del régimen de cumplimiento ambiental es posible hallar importantes zonas de responsividad, especialmente tratándose de la aplicación de sanciones, pues la Superintendencia del Medio Ambiente puede optar por el tipo de sanción a aplicar y recorrer el monto de las multas» (2016: 218).

6o. Así también en derecho ambiental. Véase el artículo 41 de la Ley 20.417. Al respecto, Bermúdez (2013).

61. Crítico ante los principios clásicos del derecho penal. 
eficacia o insuficiencia de las medidas correctivas de que dispone la Administración pública para tutelar el interés público [...]. A la tipicidad legal y a la culpabilidad se suma ahora la necesidad» (Arancibia, 2014: 146). ${ }^{62}$ En ese contexto constan medidas correctivas, antes que la sanción de multa para los administrados. Por tanto, se afirma que:

Una sanción será innecesaria en casos de infracciones menores corregidas eficazmente mediante poderes de prima ratio, pena natural, allanamiento del infractor a la sanción y efecto perjudicial para el interés que se busca proteger. Si una sanción deviene en innecesaria durante la pendencia del proceso sancionador, corresponde poner fin a dicho procedimiento mediante resolución de archivo (Arancibia, 2014: 147). ${ }^{63}$

Por tales razones la Administración no está obligada a sancionar toda y cada una de las veces, ya que existen otras medidas menos gravosas antes para emplear ${ }^{64} y$ solventar el interés público infraccionado. Nuevamente, lo notable es precisamente el objetivo primario del derecho administrativo sancionador: la tutela del interés social relevante o de la política pública pertinente. ${ }^{65} \mathrm{Al}$ respecto, esta propuesta acentúa: a) que la Administración no debe castigar toda conducta, si existen medidas menos gravosas; b) al principio de tipicidad y culpabilidad se agrega la necesidad; c) el principio de necesidad se funda en los deberes de eficacia y proporcionalidad. En consecuencia, es posible con este panorama aseverar tanto garantías mínimas (y suficientes) para futuros ciudadanos sujetos al control de la Administración, así como también asentar - en definitiva - que no todo comportamiento debe ser sancionado por la Administración desde que ella misma posee herramientas (prima ratio) para cumplir con el interés social para el cual el servicio fue creado.

Desde esta perspectiva podemos comprender la real labor que ejerce - o debería ejercer - la potestad sancionadora (reguladora) de la Administración del Estado; que

62. El mismo Arancibia (2014) expone: «Específicamente, en el ámbito administrativo, el principio de necesidad se funda en los deberes de eficacia y de proporcionalidad. Dado que la esencia de la función administrativa es la tutela del interés afectado por la infracción, la eficacia ordena ejercer primero los poderes que ponen término o enmiendan dicha perturbación antes que castigar a su autor».

63. El mismo autor destaca entre las potestades de prima ratio las advertencias, los acuerdos de autorregulación, las medidas provisionales, las órdenes terminales y el ejercicio de acciones judiciales. Lo que se corresponde con que las sanciones en derecho penal son instrumentos de última ratio.

64. «La utilización de la sanción es frecuentemente contraproducente (...) la pregunta fundamental "cuando castigar, cuando persuadir», debe responderse mediante un esquema que combine apropiadamente los sistemas sancionatorios y de persuasión» (Montt, 2010: 21).

65. «El Derecho Administrativo se orienta a la eficacia o efectividad de objetivos. Es una herramienta que permite hacer cumplir las finalidades dispuestas por las políticas públicas» (Guiloff y Soto, 2015: 104). 
pese a defender bienes jurídicos, como — básicamente- lo hace el derecho penal, ${ }^{66}$ cada cual mantiene objetivos que son bastante diversos de los así denominados fines de la pena. De tal manera, basta revisar la literatura sobre la teoría de la función de la pena ${ }^{67}$ para demostrar que detrás de la potestad sancionadora de la Administración no se halla el derecho subjetivo del Estado a castigar.

\section{La sanción como «herramienta» o «instrumento» desde la regulación responsiva}

La tesis expresada aquí no despertará interés alguno para el lector especializado, pues lo que se propone guarda especial relación con la así llamada literatura responsiva. Desde hace algunos años una respuesta similar a la aquí expresada ha identificado a la potestad sancionadora de la Administración con un sentido divergente (Braithwaite y Ayres, 1995). El anterior alcance entiende a la mentada potestad como una privilegiada herramienta de regulación, ${ }^{68}$ empero una herramienta más de regulación. Herramienta que tiene su razón de existencia en cumplir el interés general o las políticas públicas de la Administración del Estado. Por supuesto, se impone aclarar que sostener una concepción de la potestad administrativa sancionadora caracterizada como una herramienta de regulación no resulta para nada algo novedoso. De sobra conocido es su rendimiento explicativo en países de habla inglesa, con la conocida fórmula de tit-for-tat (Braithwaite y Ayres, 1995: 24-25) ${ }^{69}$ en la literatura responsiva. ${ }^{70}$

Lo que en este lugar intentamos mostrar es que: i) la potestad sancionadora es un instrumento superdotado que posee exclusivamente la Administración del Estado para mantener los fines del sistema regulado, así como las políticas públicas pertinentes; ii) esta comprensión parece ofrecer un panorama prometedor con respecto a las garantías sustantivas o procedimentales para los regulados, debido a que solo frente al incumplimiento de lo solicitado por el regulador entra en juego la sanción como «castigo» para el administrado. Por ello, si se comprende a la potestad administrativa sancionatoria como una herramienta que tiene el Estado para regular un sistema, posible es sostener principios, reglas y garantías que difieren de las que pertenecen al derecho penal. En este orden de cosas, la sanción de multa será la excepción y la

66. Acerca de qué protege la norma de sanción, véase Hefendehl (2007: 179-196). Para la inquietante interrogante a hechos punibles sin protección de un bien jurídico palpable, véase Hassemer (2007: 95-104).

67. Véase Guzmán Dalbora (2008: 327). En la discusión comparada, véanse los renombrados Jakobs (1997: 43-76) y Roxin (1997: 49-77).

68. En Chile pueden verse Montt (2010: 18 y ss) y Guiloff y Soto (2015: 103 y ss).

69. En su traducción al español: «toma y daca».

70. «La responsividad en materias regulatorias significa que las acciones que adopta la Administración dependen de la estructura y motivaciones del respectivo sector regulado y sus actores» (Guiloff y Soto, 2015: 104). 
regla general la colaboración mediante advertencias al regulado. La reflexión parece obligatoria si se piensa desde una visión funcional ${ }^{71}$ del sistema de distribución de competencias entre el área administrativa y la penal.

Después de una breve revisión a la legislación chilena, es plausible reconocer que el ordenamiento jurídico ha comenzado a avanzar hacia este punto, con las últimas leyes sobre agencias reguladoras. Es el caso, por ejemplo, de la creación de la Superintendencia del Medio Ambiente, y sus programas de cumplimiento ${ }^{72}$ previos a la imposición de una sanción; y de la creación de la Superintendencia de Educación, dado que su Ley 20.529, en particular el artículo 59, permite que «formulada una denuncia o recibido un reclamo, la Superintendencia podrá abrir un período de información previo con el fin de conocer las circunstancias concretas del caso y la conveniencia de iniciar un procedimiento sancionatorio o la respectiva mediación». Por lo que tampoco es necesario imponer la sanción de multa como prima ratio, sino por el contrario evaluar la «conveniencia de iniciar un procedimiento sancionatorio».

\section{Jurisprudencia judicial}

Los pronunciamientos de nuestras altas Cortes de Justicia no han sido la excepción a la hora de tomar posición sobre esta problemática. Algunos enuncian - con razón- que la Corte Suprema de Chile se hallaría en torno a la tesis de la diferencia cuantitativa a la que subyace el argumento magnificado de la génesis común en el ius puniendi estatal..$^{73}$ En lo que sigue se hará mención sólo a algunos pronunciamientos que han resultado de peculiar interés.

71. Correctamente se ha apuntado que: «La perspectiva funcional exige que las sanciones administrativas sean diseñadas y aplicadas responsivamente. Esto significa que el regulador debe estar dotado de herramientas que le permita recorrer opciones que van desde la persuasión hasta la inhabilitación del administrado» (Soto, 2016: 207).

72. Ley 20.417, publicada en el Diario Oficial el 28 enero de 2016: «Artículo 42. Iniciado un procedimiento sancionatorio, el infractor podrá presentar en el plazo de 10 días, contado desde el acto que lo incoa, un programa de cumplimiento».

73. Señalando que: «Tanto la Contraloría General de la República, el Tribunal Constitucional y la Corte Suprema han sido seducidos en diversos casos por la teoría cuantitativa en mayor o menor medida, aun cuando el caso Pollos terminó por devolver la discusión a fojas cero» (Rodríguez Collao, 1987: 544). Como se verá más adelante, el Tribunal Constitucional en el Caso Pollos negó a los ejecutivos de las empresas el derecho a no autoincriminarse, para permitir que rindieran su absolución de posiciones, en el procedimiento ventilado ante el Tribunal de Libre Competencia. 


\section{El Caso Mackenna (Chispas II): ${ }^{74}$ ¿Son personalísimas} las sanciones (multas) que impone la administración?

En el caso de marras, los hechos tenían relación con un problema cardinal. El máximo tribunal debió manifestar su decisión en relación a una persona multada por la SVS que había perecido días previos a que la Corte Suprema denegara la reclamación contencioso administrativa contra la multa impuesta. De esta manera - alegaron los recurrentes-, mientras no se resolvieran los recursos jurisdiccionales, la decisión administrativa no estaría firme y ejecutoriada. Este hecho, de la mano del conocido principio de personalidad de las penas, ${ }^{75}$ provocaba que los herederos no debiesen estar obligados a pagar las multas de su causante. La decisión enunció apreciables cuestiones de las que escogemos exponer tres. En primer lugar, el fallo constata que en nuestro país perdura una carencia legislativa específica. ${ }^{7}$ Este déficit se localiza en la regulación positiva del procedimiento administrativo sancionatorio y a la par de sus sanciones administrativas. En segundo lugar, la Corte Suprema concibe que la extrapolación absoluta y completa de garantías penales se torna compleja y difícil, por cuanto teóricamente, como ya mencionamos, el aparato de persecución penal, esto es, la pretensión punitiva de monopolio estatal, tiene distintos objetivos ${ }^{77}$ de los perseguidos por la potestad administrativa sancionadora. ${ }^{78}$

74. Para un análisis detallado del caso, véase Zúñiga (2015: 414), cuya exposición se sigue de cerca aquí.

75. Para una exposición del origen del principio de personalidad de penas y la consecuente intransmisibilidad de la penas, véase Beccaria (1995: 52), quien al respecto manifestó en su concepción, que la transmisión de las penas pecuniarias e infamantes a los parientes del delincuente eran «injusticias autorizadas y repetidas», que en el pasado se habían tolerado por los hombres más iluminados y ejecutado en la repúblicas más libres «por haber considerado la sociedad no como unión de hombres, sino como unión de familias»; citado a su vez por Ramos (2005: 245-278). En criterio de Contraloría General de la República, el principio de personalidad en la imposición de sanciones se observa en los dictámenes 29.079 de 1989 y 11.463 de 1985.

76. En la sentencia de la Corte Suprema en la causa Fisco con Dorr Zegers, rol 1.079-2014, señala en considerando noveno: «dicha carencia legislativa y el común origen de ambas sanciones no autorizan para aplicar de manera automática las normas y principios propios del derecho penal al derecho administrativo sancionador, sino que tal aplicación debe efectuarse dentro de los márgenes del procedimiento administrativo en general y del sancionatorio en particular, sin perder de vista el contexto que tuvo en vista el legislador para optar por una u otra sanción».

77. En la sentencia de la Corte Suprema en la causa Fisco con Dorr Zegers, rol 1.079-2014, señala en considerando noveno: «para garantizar, de un modo más eficaz, los intereses sociales que en dichos ámbitos se encuentran en juego, lo que en caso alguno implica afirmar que, por ello, la Administración queda libre del control jurisdiccional en su obrar material y jurídico».

78. En la sublimación de la tesis del único ius puniendi estatal puede verse la uniforme jurisprudencia, en la sentencia de la Corte Suprema, rol 9.605-2015, considerando cuarto: «Por lo demás, esta Corte Suprema ha resuelto en forma reiterada que la potestad sancionadora de la Administración admite un origen común con el derecho penal, en el ius puniendi del Estado, por lo que resultan aplicables los mis- 
En fin, se desestimaron los argumentos de los recurrentes y se mantuvo la multa como transmisible para que sea pagada por los herederos del causante..$^{79}$ Como se ha destacado, la decisión regresa a un asunto algo olvidado. ${ }^{80}$ La sanción es impuesta por medio de un acto administrativo y en el marco de un procedimiento - justamenteadministrativo (sancionatorio). Con tal pensamiento se razona que los actos administrativos se insertan en el ordenamiento jurídico con la idea de ejecutoriedad, ${ }^{81} \sin$ que sea necesario un visto bueno u otra actuación de autoridad (judicial o no) para encontrarse en estado de cumplirse.

En consecuencia, es posible atestiguar que el máximo tribunal chileno permite anunciar que la respuesta a los principios aplicables para el derecho administrativo sancionador, debe encontrarse primariamente en sus reglas como rama autónoma del ordenamiento jurídico. ${ }^{82}$ Cabe precisar que se comienza a evidenciar con rigor el incipiente abandono del simplismo principialista que irroga la tesis del ius puniendi. De modo secundario se reconoce que existen principios transversales al sistema normativo ya sea penal o ya sea administrativo. Estos principios derivan en verdaderas

mos principios, límites y garantías que en la Carta Fundamental se prescriben para el derecho punitivo, aunque ese traspaso haya de producirse con ciertos matices en consideración a la particular naturaleza de las contravenciones administrativas».

79. Véase el considerando decimotercero de la sentencia de la Corte Suprema, rol 1.079-2014 (Caso Mackenna), el que dirime la cuestión: «los efectos del acto administrativo que impuso la multa al sr. Mackenna se radicaron en su patrimonio al momento en que fue notificado de la misma». En contra de la transmisibilidad de las multas, véase Mendoza (2004: 135), para quien la multa es derechamente una pena.

80. «La decisión administrativa sancionatoria es ante todo un acto administrativo, y, en tanto tal, participa de todas las características de ese acto» (Letelier, 2015: 322).

81. Sobre la distinción entre ejecutoriedad del acto administrativo y ejecutividad, Letelier clarifica que: «En paralelo a esta idea de ejecutoriedad $-\mathrm{y}$ esto es lo que muchas veces se confunde- encontramos también el concepto de ejecutividad, que dice relación con la fecha en que los actos administrativos despliegan los efectos que le son propios. Mientras la ejecutoriedad se vincula con la capacidad de crear cargas, obligaciones o derechos, la ejecutividad dice relación con la eficacia de ellas» (2015: 326).

82. Prueba de tal afirmación se encuentra en la solución que la Corte Suprema dispone para aquellas situaciones en que se ha producido una innecesaria dilación en el administrativo sancionador. Así, por ejemplo, en la tardanza en la formulación de cargos, en la notificación de los mismos, o, en definitiva, en la resolución que pone término al mismo y comunica la sanción. Al respecto, Cordero Vega (2010: 243-255) arguye que, si bien reconoce la necesidad de resolver esta disyuntiva, se conocen otros medios a los cuales recurrir aplicando la Ley de Bases de Procedimientos Administrativos vigente. Este autor discrepa comentando que: «los remedios correctos son lo que la literatura conoce como terminación anormal de los procedimientos, que se traduce, en los casos de incumplimiento de plazos, en caducidad o abandono, y silencio administrativo» (2010: 253). Y lo que distingue al «procedimiento administrativo sancionatorio es ante todo un procedimiento administrativo que se instruye precisamente para la dictación de un acto terminal sujeto a los plazos que establece la ley» (2010: 254). 
garantías del ciudadano para desenvolverse en libertad en un Estado democrático. ${ }^{83}$ Ahora bien, lo que se rebate en estas líneas no es justamente la existencia de tales principios y/o garantías, sino que pueda hallarse simplemente en un supraconcepto normativo, o en un simplismo principialista, ${ }^{84}$ como se pretende por una amplia doctrina nacional.

\section{A falta de regla expresa con qué suplir: ¿Prescripción penal o civil? ¿Culpabilidad penal o civil?}

Como cuestión previa cabe precisar que la Corte Suprema ${ }^{85}$ conforme a los principios sustantivos presentes en el derecho administrativo sancionador, reiteradamente ha precisado los alcances de estos principios. En particular para el derecho sancionatorio (administrativo), no hay dudas de que rige el principio de legalidad. Lo anterior quiere decir que, por exigencia de legalidad, las conductas reprochables como las sanciones con que se las castiga deben estar previstas en la ley. No obstante, «la naturaleza de las contravenciones administrativas en las que confluyen componentes técnicos, dinámicos y sujetos a variabilidad en el tiempo, hace imposible su síntesis descriptiva en un precepto general como lo es una ley, de modo que el principio de tipicidad al traspasarse al ámbito sancionatorio de la Administración admite ciertos grados de atenuación». ${ }^{86}$

83. En este sentido, Politoff señala que: «Los abusos a que tales medidas — sanciones administrativas- pueden conducir, explican los graves reparos que suscita su utilización, sobre todo cuando ella quebranta los criterios de respeto de la dignidad y de los derechos fundamentales de la persona que debe servir de freno a los excesos del poder político» (1997: 37).

84. Letelier pone en evidencia esta primera búsqueda de principios penales al derecho administrativo sancionador: «Luego de aquella primera búsqueda principialista de garantías penales a aplicar, se ha continuado con la desfiguración de éstas para, finalmente, acercarse a la respuesta que el derecho administrativo podría haber ofrecido con un análisis más profundo, funcional y complejo» (2015: 319).

85. La jurisprudencia judicial sigue un concepto estricto de sanción administrativa, relativo tanto al carácter preventivo respecto de determinadas conductas consideradas, como a los ilícitos administrativos. Así también uno de índole represivo, en respuesta a la infracción cometida. Así, el máximo tribunal anota que: «la sanción administrativa tiene principalmente una finalidad preventivo-represora, con ella se persigue el desaliento de futuras conductas ilícitas similares, se busca reprimir la conducta contraria a derecho y restablecer el orden jurídico previamente quebrantado por la acción del transgresor» (sentencia de la Corte Suprema, rol 4.922-2010, considerando sexto). En la misma línea está la sentencia de la Corte Suprema del 29 de octubre de 2010, rol 9.078-2009, considerando noveno, y, de la misma fecha, la causa rol 2.090-2010, considerando noveno.

Sentencias de la Corte Suprema, roles 4.404-2005, 7.117-2008, 8.568-2009 y 1.205-2009.

86. Sentencia de la Corte Suprema, rol 24.563-2014, Servicio Nacional de Pesca con Empresa Exportadora Los Fiordos Limitada, considerando sexto y séptimo. Sobre esta atenuación de tipicidad, véase la sentencia de la Corte Suprema, rol 5.209-2011, Thyssen Krupp Aceros y Servicios S.A. con Secretaría Regional Ministerial de Salud de la Región de Antofagasta. 
A la interrogante sobre qué sucede cuando una ley no tiene normas especiales sobre prescripción de la potestad administrativa sancionatoria, ¿a qué cuerpo legal debemos remitirnos? Frente a tal vacío normativo, ¿qué regla debe suplir la omisión del legislador? ¿Es del caso resolver la problemática con el Código Penal o bien con el Código Civil u otro cuerpo legal? Al respecto, el máximo tribunal de la República, durante el año $2012,{ }^{87}$ sostuvo la improcedencia de aplicar las reglas civiles a esta materia y sostuvo que lo correcto era la utilización de la prescripción para las faltas. En tal sentido, argumentó — como lo hace la Contraloría General de la República— ${ }^{88}$ que las reglas aplicables a la materia son las reglas determinadas para las faltas penales, ${ }^{89}$ en el entendido de que las contravenciones administrativas están enmarcadas propiamente en el campo del derecho público y son equivalentes al hecho punible de menor envergadura que contempla nuestro ordenamiento jurídico. ${ }^{90}$

La Corte Suprema se ha inclinado en la actualidad por una tesis distinta. En efecto, ha preferido aplicar el código de Bello de la norma rectora de la regulación civil ${ }^{91}$

87. Sentencia de la Corte Suprema, rol 78-2010, Instituto de Salud Pública con Laboratorios Recalcine S.A., sentencia de casación, dictada el 9 de abril de 2012.

88. La Contraloría General de la República, dado que afirma que la potestad sancionatoria proviene de un único ius puniendi estatal, define que el plazo de prescripción es el de seis meses del Código Penal para las faltas. Cf. Dictamen 14.571 de 2005. En misma línea de pensamiento, véase el Dictamen 31.239 del año 2005.

89. En sentencia de la Corte Suprema, rol 78-2010, Instituto de Salud Pública con Laboratorios Recalcine S.A., sentencia de casación, dictada el 9 de abril de 2012. En su considerando noveno estima que: «Que al término de las reflexiones anteriores no cabe sino concluir, en congruencia con las ideas en ellas expresadas - que han sido, en lo esencial, compartidas por la jurisprudencia reiterada de esta Corteque, en ausencia de una regla específica sobre el punto, las infracciones y sanciones administrativas deben prescribir en el plazo de seis meses establecido para las faltas en los artículos 94 y 97 del Código Penal». Similar conclusión se encuentra en sentencia de la Corte Suprema, rol 2501-2010, Instituto de Salud Pública con otros, sentencia de casación, dictada el 2 de abril de 2012.

90. Esta opinión se observa en la sentencia de la Corte Suprema, rol 78-2010, considerando séptimo: «Que corresponde desestimar, asimismo, la opinión - que también suele sustentarse- proclive a aplicar supletoriamente en el derecho administrativo sancionador el plazo de cinco años establecido en el artículo 2.515 del Código Civil para la prescripción de largo tiempo, propia de las acciones ordinarias vinculadas al derecho de las obligaciones, tanto por la distinta naturaleza que ostentan las acciones relativas al ámbito sancionatorio — de indiscutible pertenencia al campo del derecho público-y aquéllas que sirven para salvaguardar las acreencias del derecho común, inspiradas en principios jurídicos pertenecientes al orden privado y reguladas en dicho Código, como en razón de los fundamentos sobre los que reposa el instituto de la prescripción extintiva».

91. Sobre el estándar de culpa infraccional para distinguir la responsabilidad civil de la penal, se ha dicho que: «En la culpa infraccional se muestra claramente la diferencia que existe entre la responsabilidad civil y penal en materia de culpabilidad. En efecto a diferencia de lo que ocurre en materia penal, la culpa civil puramente infraccional no requiere ser completada con una imputación subjetiva del ilícito. Por eso, el error de prohibición, que suele ser excusa suficiente en materia penal, sólo excepcionalmente tiene lugar en materia civil. En la medida que la culpa es concebida como infracción a un deber de cui- 
como estándar de culpa infraccional, ${ }^{92}$ así como en otra arista sobre la problemática que dice relación con los plazos de prescripción en materia de derecho administrativo sancionador. La Corte Suprema confirmó su criterio de que ante la ausencia de norma expresa, deben aplicarse las reglas del derecho común, esto sería -a juicio del tribunal- el Código Civil. ${ }^{93}$ La Corte Suprema, al escoger esta tesis, ${ }^{94}$ ha optado por las reglas del sistema civil ${ }^{95}$ (cinco años) antes que las del sistema penal (faltas sesis meses). ${ }^{96}$

Conjuntamente, se ha optado por la aplicación de normas civiles en lo que se refiere al principio de culpabilidad, ${ }^{97}$ asimilado a la culpa infraccional. ${ }^{98}$ Así, el estándar del debido cuidado estaría previamente consagrado por lo que los regulados del ámbito sectorial podrían estar en condiciones, generalmente, para conocer del mismo. Por tanto, en el desempeño de las actividades tipificadas administrativamente el principio de culpabilidad del derecho administrativo sancionador puede resultar análogo

dado, son irrelevantes las circunstancias subjetivas en cuya virtud se produjo la contravención» (Barros, 2006: 98-99).

92. Una exigencia análoga se observa en el caso de la SVS con Sebastián Piñera Echeñique, resolución exenta 306, del 6 de julio de 2007, p. 15: «En consecuencia, el elemento de culpabilidad del infractor se establece en su falta de diligencia y cuidado al no adoptar medidas de prudencia o precaución que pudieran evitar que incurra en la conducta prohibida».

93. Sentencia de la Corte Suprema, rol 3.528-2015, Fernando Albala Chamudes con Instituto de Salud Pública, considerando vigésimo, en que se aplicó el criterio de la prescripción civil para resolver la problemática. Así reza el considerando: «Que, entonces, el defecto normativo de omisión de un plazo razonable y prudente de prescripción, en que incurriera el legislador, impone el deber de encontrar en la legislación positiva, actual y común, la solución del problema que ha sido promovido debiendo por ello acudirse a las normas generales del derecho común dentro del ámbito civil y, en ese entendido, hacer aplicación a la regla general de prescripción extintiva de cinco años a que se refiere el artículo 2.515 del Código Civil». En contra, véase Vergara (2009: 45-68).

94. Sentencia de la Corte Suprema, rol 24.233-2014, Aguas Araucanía S.A. con Comisión Nacional del Medio Ambiente, considerandos duodécimo y decimotercero.

95. El Código Civil chileno reza: «Artículo 2.515. Este tiempo es en general de tres años para las acciones ejecutivas y de cinco para las ordinarias».

96. El Código Penal chileno preceptúa que: «Artículo 94. La acción penal prescribe: [...] Respecto de las faltas en seis meses».

97. Sentencia de la Corte Suprema, rol 24.233-2014, Aguas Araucanía S.A. con Comisión Nacional del Medio Ambiente, considerandos duodécimo y decimotercero.

98. La Corte Suprema opta por seguir el camino planteado por Cordero Vega, quien se pronuncia: «Al ser el legislador, o bien la autoridad pública, según el caso, quien viene en establecer el deber de cuidado debido en el desempeño de las actividades tipificadas, cabe asimilar el principio de culpabilidad del derecho administrativo sancionador al de la noción de la culpa infraccional, en la cual basta acreditar la infracción o mera inobservancia de la norma para dar por establecida la culpa; lo cual se ve agravado en los casos que se trate de sujetos que cuenten con una especialidad o experticia determinada, donde el grado de exigencia a su respecto deberá ser más rigurosamente calificado» (2015: 503-504). En mismo sentido, Oksenberg y Flores (2009). 
a la noción de la culpa infraccional que conoce el derecho civil. En esta área del derecho es suficiente para confirmar la infracción una mera inobservancia de la norma para así dar por fundada la culpa ${ }^{99} \mathrm{y}$ la consecuente responsabilidad por la infracción.

\section{Debido proceso y actuación de la agencia estatal. El Caso Corpbanca ${ }^{100}$}

Recientemente, una interesante decisión ha emanado de la Corte de Apelaciones en relación al debido proceso que debe regir los procedimientos administrativos de sanción. La Corte anuló ${ }^{101}$ la multa de aproximadamente 30 millones de dólares impuesta al Banco Corpbanca, ${ }^{102}$ mediante la reclamación interpuesta por Corpbanca, y previo entero de la multa aplicada por la SBIF. ${ }^{103}$

La Corte se hace cargo latamente de los requisitos mínimos de todo procedimiento administrativo sancionatorio, ${ }^{104}$ de cara a lo que debiese contener para no contravenir la «macrogarantía» del debido proceso. Al efecto, expresa que: «no obstante, aunque se trate de potestades que no suponen ejercicio de jurisdicción, ciertamente deben sujetarse a los parámetros propios de un debido proceso» ${ }^{105}$ vale decir jus-

99. Sentencia de la Corte Suprena, rol 24.233-2014, considerando duodécimo: «la circunstancia de que un régimen de responsabilidad no se cimiente en la culpa del autor, no lo transforma en inconciliable con nuestro ordenamiento, desde que un sistema objetivo o estricto no viola el principio constitucional de la presunción de inocencia».

10o. Sentencia de la Corte Suprema, rol 644-2016. En la actualidad, pendiente recurso de queja, del 30 de septiembre de 2016, presentado por la SBIF, rol 62.128-2016.

101. Corpbanca hizo uso de la reclamación del artículo 22 de la Ley General de Bancos, que ordena: «El reclamo deberá formularse dentro del plazo de diez días contado desde el entero de la multa, siempre que dicho entero se haya efectuado dentro del plazo».

102. El último no ocurría desde 1996, cuando la entidad fiscalizadora sancionó al Banco Edwards, aunque no por la misma causal, pero sí por créditos relacionados, conforme destaca la prensa nacional (véase El Mostrador, «Eric Parrado desafía a la Corte de Apelaciones y eleva caso de millonaria multa contra CorpBanca a la Corte Suprema», disponible en http://bit.ly/2rVuWDH).

103. Este es uno de los últimos resabios del solve et repete. Sobre su polémico carácter, véase la sentencia del Tribunal Constitucional, rol 1.345-2009, que declaró inconstitucional el artículo 171 del Código Sanitario: «Para dar curso a ellos se exigirá que el infractor acompañe el comprobante de haber pagado la multa». Incompatible con la Constitución, según Soto Kloss (2006: 97-117).

104. En la reciente sentencia del Tribunal Constitucional, rol 2.701-2014, el Tribunal efectúa un completo análisis del debido proceso. El fallo ofrece una reflexión con respecto a dos grandes familias de derechos procesales que se encuentran insertas dentro del artículo 19, número 3, de la Constitución. Su propia jurisprudencia (sentencias roles 815 , considerando décimo; 1470, considerando noveno, y 1535 , considerando decimoctavo, entre otras) ha diferenciado entre el derecho a la tutela o protección judicial efectiva y el derecho al debido proceso.

105. Considerando sexto, octavo, vigésimo cuarto, de la sentencia del Tribunal Constitucional, rol 1518-2009. De idéntico tenor, la sentencia del mismo tribual rol 725-2007, sobre las facultades del Director Regional de Servicio de Impuestos Internos. 
to y racional (Aróstica, 2008: 85). ${ }^{106}$ A este tenor especifica como elementos: «i) la oportuna comunicación al eventual afectado de la pretensión punitiva [sic] de la administración, lo que ordinariamente se materializa en una acusación o formulación de cargos; ii) la posibilidad de que el afectado plantee defensas o alegaciones; iii) la posibilidad de que el afectado rinda prueba». ${ }^{107}$

En mérito de los antecedentes que se acompañaron al proceso, el colegiado tribunal pudo sentar como hechos: que la SBIF realizó un proceso de fiscalización al recurrente Corpbanca a propósito del hecho público y notorio del nombramiento en el mes de septiembre de 2015 del señor Rafael Giulisasti en el cargo de Director y Presidente, en reemplazo de don Julio Ponce Lerou, en las Sociedades Norte Grande S.A., Inversiones Oro Blanco S.A. y Pampa Calichera S.A. Todas integrantes del grupo conocido periodísticamente como «Cascadas». ${ }^{108}$ Fue en tal escenario que el ente regulador requirió antecedentes en relación a tres operaciones comerciales por estimarse que dicho banco había excedido el límite individual de crédito establecido por el número 1 del artículo 84 de la Ley General de Bancos. Más tarde se impusieron tres multas, que se materializaron mediante el envío de una carta de fecha 30 de diciembre de 2015, correspondiendo la misma al acto impugnado. ${ }^{109}$

Los sentenciadores - certeramente- opinan que el debido proceso no se corresponde necesariamente con el que instituya una ley, toda vez que debido proceso es aquel en que efectivamente existen condiciones de racionalidad que aseguren la justicia. De manera que si la ley así no lo consagra, este no puede considerarse apegado al régimen constitucional — ni mucho menos, agregamos- legitimado frente a los administrados. ${ }^{110}$ Debe tenerse en cuenta (como bien manifiesta la sentencia) que la impugnación de multas no es más que objetar un acto administrativo. ${ }^{111}$ Acto jurídico que en la Administración del Estado conoce de cualidades y características excepcionales. Así, para ilustrar el punto, dentro del ordenamiento jurídico son excepcio-

106. «Porque admitido este derecho-garantía reaccional, cuya finalidad es mantener la integridad de los demás derechos conculcados por la autoridad la conclusión necesaria es que lo cubre y pone a salvo la misma Carta Fundamental».

107. Sentencia de la Corte de Apelaciones, rol 644-2016, del 31 de agosto de 2016, p. 245, considerando primero.

108. De forma similar, la sentencia de la Corte de Apelaciones, rol 644-2016, del 31 de agosto de 2016, p. 274, considerando cuarto letra a).

109. Parafraseando a la sentencia de la Corte de Apelaciones, rol 644-2016, considerando cuarto letra b). 110. Sentencia de la Corte de Apelaciones, rol 644-2016, considerando quinto, p. 275.

111. El fallo de la Corte de Apelaciones, en su considerando octavo, p. 276, efectúa un distingo entre procedimientos administrativos de impugnación (recursos frente a la Administración) y los procesos administrativos (dirigidos para un tribunal de justicia). Así, en el primero de ellos se puede revisar la legalidad de la actuación, la oportunidad y el mérito de ésta. En cambio, en los segundos, solo cabe la revisión de la legalidad del acto u omisión de la Administración, ya que están sujetos estrictamente al principio de legalidad. 
nales, por cuanto gozan de una cierta presunción de legalidad o validez ${ }^{112}$ desde su inicio, lo que lleva aparejada su ejecutividad, ejecutoriedad y aun su ejecución forzosa en ciertos casos (artículos 3 y 51 de la Ley 19.88o, sobre Bases de Procedimientos Administrativos). ${ }^{113}$ Es por este razonamiento y no por supuestamente revestir un origen común con el derecho penal. ${ }^{114}$ Puesto que los bienes jurídicos a tutelar, por relevantes que sean, no eximen en manera alguna que las facultades del organismo se manifiesten contra una estricta sujeción al debido proceso. ${ }^{115}$

La Corte de Apelaciones en definitiva debió resolver si el acto administrativo terminal que aplicó el órgano regulador tuvo ocasión de revestir los estándares mínimos sobre debido proceso que integran todo procedimiento administrativo. Para ello, y en razón de las normas constitucionales pertinentes — artículo 19 número 3, artículo 63 número 18, entre otras-, pese lo prescrito por el artículo 1 de la Ley General de Bancos, ${ }^{116}$ el tribunal estima que debe entenderse tácitamente derogado por la Ley Orgánico Constitucional 18.575, tanto como ley posterior ${ }^{117}$ en cuanto jerárquicamente superior según afirma la misma Corte. ${ }^{18}$ Que, a su vez, vino a cumplir el mandato expresamente dispuesto en el artículo 38 de la Constitución. Por tanto, la SBIF se encuentra sujeta al principio de supremacía constitucional (artículo 6 y 7 de la Constitución) garantizado por el artículo 19 número $26 .{ }^{119}$ En este orden de ideas, es un

112. Cf. Aróstica (1991). Cita online: CL/DOC/2172/2011.

113. Cf. la sentencia de la Corte de Apelaciones, rol 644-2016, considerando séptimo, p. 276.

114. En palabras de la resolución que abordamos: «Por ello es que resulta especialmente relevante que tal acto administrativo haya cumplido con las exigencias de un debido procedimiento administrativo sancionatorio previo, con una debida fundamentación y contradictoriedad, única forma de hacer efectivo el derecho a su impugnación con pleno conocimiento de los antecedentes tanto del procedimiento llevado a cabo como de los fundamentos de la decisión adoptada» (considerando séptimo en la sentencia de la causa rol 644-2016, de la Corte de Apelaciones).

115. Sentencia rol 644-2016, considerando decimocuarto, p. 291.

116. En relación a la última disposición legal citada, la Ley General de Bancos en su artículo 1, en lo pertinente, indica que: «La Superintendencia de Bancos e Instituciones Financieras es una institución autónoma, con personalidad jurídica, de duración indefinida que se regirá por la presente ley y se relacionará con el Gobierno a través del Ministerio de Hacienda. Su domicilio será la ciudad de Santiago y no obstante su carácter de derecho público, no se considerará como integrante de la administración Orgánica del Estado ni le serán aplicables las normas generales o especiales dictadas o que se dicten para el sector público y, en consecuencia, tanto la Superintendencia como su personal se regirán por las normas del sector privado, sin perjuicio de lo que dispone el artículo 5».

117. La Ley General de Bancos, contenida en Decreto con Fuerza de Ley 3, del Ministerio de Hacienda, tiene por fecha el 26 de noviembre de 1997, sin perjuicio de ello su original es el artículo único del Decreto con Fuerza de Ley 252, de 1960.

118. Parafraseando sentencia de la Corte de Apelaciones, rol 644-2016, considerando undécimo, p. 287. 119. La Corte de Apelaciones cita la sentencia del Tribunal Constitucional 478, aclarando que: «en causa rol 478 al señalar que: los principios del artículo 19 de la Constitución, en la amplitud y generalidad ya realzada, se aplican, en lo concerniente al fondo o sustancia de toda diligencia, trámite o procedimiento, 
servicio público que integra la Administración del Estado, por ende es aplicable el régimen jurídico propio de dichos organismos. ${ }^{120}$

En síntesis, se estableció que el acto terminal de la SBIF careciendo de normas especiales para el procedimiento sancionatorio debió, al menos, recurrir (necesariamente) al procedimiento consagrado en la Ley de Bases de Procedimientos Administrativos: "pues ésta es siempre aplicable en la Administración ante la falta de un procedimiento propio». ${ }^{121}$

\section{Jurisprudencia constitucional}

El Tribunal Constitucional ha seguido en buena parte la dominante doctrina nacional, identificando sanciones administrativas y penales dentro de la actividad punitiva del Estado. ${ }^{122}$ En este sentido, la magistratura constitucional ha comprendido que los principios del derecho penal son aplicables por regla general a la potestad sancionadora de la Administración. ${ }^{123}$ Más tarde, el Tribunal cambiaría la expresión por una «matizada» aplicación de los principios penales al derecho administrativo sancionador, atendida la supuesta naturaleza inherentemente punitiva de esta potestad. La tesis consiste en mostrar explícitamente que la Administración estatal y sus agencias (superintendencias) en cualquiera de sus vertientes —incluida la sancionadora- están sujetas al principio de legalidad o juridicidad. ${ }^{124}$ Desde luego, el argumento de texto se manifiesta en virtud de los preceptos 6 y 7 de la Constitución, que a su turno instituyen la atadura de los órganos del Estado al ordenamiento jurídico. En este orden de ideas, nos permitimos reproducir in extenso, una de las conclusiones, del colegiado tribunal:

Que el principio de legalidad es igualmente aplicable a la actividad sancionadora

cualquiera sea el órgano estatal involucrado, trátese de actuaciones judiciales, actos jurisdiccionales o decisiones administrativas en que sea o pueda ser, afectado el principio de legalidad contemplado en la Constitución, o los derechos asegurados en el artículo 19 de ella, comenzando con la igual protección de la ley en el ejercicio de los atributos fundamentales».

120. Sentencia de la Corte de Apelaciones, rol 644-2016, considerando duodécimo. Por su parte, el artículo 2 de la Ley 18.575 contempla que: «Los órganos de la Administración del Estado someterán su acción a la Constitución y a las leyes. Deberán actuar dentro de su competencia y no tendrán más atribuciones que las que expresamente les hayan conferido el ordenamiento jurídico».

121. Considerando decimocuarto de la sentencia de la Corte de Apelaciones, rol 644-2016, p. 291.

122. Véase Navarro (2014: 17-37). En el mismo sentido, Zúñiga (2015: 405).

123. La postura del Tribunal Constitucional, como se sabe, fue influenciada primordialmente por el Tribunal Constitucional español; que como se señaló más arriba, expresó que los principios del orden penal son aplicables con matices al derecho administrativo sancionador.

124. Así, señala que: «No obstante divergencias naturales entre las opiniones de los autores, es usual sostener que el principio de juridicidad está contenido, ya sea íntegramente en el artículo 7 , o conjuntamente en los artículos 6 y 7» (Moraga, 2008: 301). 
de la administración en virtud de lo prescrito en los dos últimos incisos del numeral 3 del artículo 19 de la Carta Fundamental. Aun cuando las sanciones administrativas $\mathrm{y}$ las penas difieren en algunos aspectos, ambas pertenecen a una misma actividad sancionadora del Estado -el llamado ius puniendi- y están, con matices, sujetas al estatuto constitucional establecido en el numeral 3 del artículo $19 .{ }^{125}$

A grandes rasgos, el párrafo del Caso Eléctricas ${ }^{126}$ recién transcrito respondió a la consulta atingente de si una ley puede habilitar a una superintendencia para aplicar sanciones. La disputa presentó la circunstancia de que una norma legal faculte a una superintendencia para sancionar — por medio de normas infra legales- no constituye un acto constitucionalmente repudiable desde el punto de vista de la legalidad en su dimensión de reserva legal. ${ }^{127}$ Recapitulando, es plausible sostener que las normas infralegales - reglamentos generalmente- ${ }^{128}$ se limiten a ordenar deberes adecuadamente detallados, pero sí sólo si aquellos se hallan con anterioridad en normas de rango legal. De esta manera, es posible sostener la incorrección que supone apoyar derechamente la aplicación en bloque de garantías penales al derecho administrativo sancionador. Ya que es improcedente por ser materias que si bien tienen, tanto una como otra, normas de «castigo» (mejor: de sanción) poseen orientaciones o fines de carácter disímil. Son nuevamente los objetivos, fines o metas de cada rama del ordenamiento jurídico lo que permite proponer una sustantivación del derecho administrativo sancionador. ${ }^{129}$ Por lo demás, el derecho penal permite afectar bienes

125. Considerando quinto de la sentencia del Tribunal Constitucional, rol 480, Caso Eléctricas.

126. Sentencias del Tribunal Constitucional, rol 480-2006, del 27 de junio de 2006, considerando cuarto y rol 479-2006, considerando sexto, Caso Eléctricas.

127. Considerando vigésimo octavo de la sentencia del Tribunal Constitucional, rol 480-2006, así se recalca por el Tribunal que «es obvio, por la correcta definición del principio de reserva legal, que si el deber está establecido en una norma de rango legal, no cabe reproche de constitucionalidad alguno en su virtud».

128. Sobre la "colaboración reglamentaria» para definir conductas, y sin perjuicio de la reserva legal, como garantía formal se ha entendido que esta formalidad no excluye morigeraciones y consecuentemente la intervención del reglamento es lícita. Por ejemplo, la sentencia 61-199o del Tribunal Constitucional español acerca de la reserva legal que «ha sido considerada a veces susceptible de minoración o de menor exigencia en supuestos de remisión de la norma legal a normas reglamentarias, si en aquella quedan suficientemente determinados los elementos esenciales de la conducta antijurídica [...] y la naturaleza y límites de las sanciones a imponer». En Chile puede verse la sentencia del Tribunal Constitucional rol 480-2006, considerandos decimoquinto y decimoséptimo, Caso Eléctricas.

129. Considerando décimo de la sentencia del Tribunal Constitucional, rol 480-2006: «Aunque se adopte entonces la doctrina que asimila ambos sistemas, se hace necesario luego reconocer las diferencias y construir una línea jurisprudencial y doctrinaria propia del derecho administrativo, en conformidad a los principios de esta rama y teniendo especialmente presente las garantías patrimoniales y de la libertad económica y no las de la libertad personal, cuando son las primeras y no las segundas las que están en juego». 
jurídicos como la libertad personal en derecho administrativo sancionador, resulta absolutamente improcedente. Los bienes jurídicos atingentes a este campo del derecho derivan en el otorgamiento de garantías patrimoniales, primordialmente, la libertad económica. ${ }^{130}$

En otros términos, mientras el derecho penal supone la atribución culpable $e^{131} \mathrm{de}$ una sanción (pena) al ciudadano por la acción u omisión imputable - a título de dolo o culpa - en el quebrantamiento de una norma de conducta, ${ }^{132}$ el derecho administrativo sancionador tiene por objetivo sancionar a un funcionario por incumplimiento de ciertos deberes (sanción disciplinaria). ${ }^{133}$ Ya sean estos deberes propios de la función encomendada en razón de su cargo (relación de sujeción especial), o bien atribución de responsabilidad a los administrados por infracción de los deberes específicos con motivo de su actuación en una actividad regulada (relación de sujeción general). Sin duda que a su turno ambos redundan en una protección de la intangibilidad del ordenamiento jurídico ${ }^{134} \mathrm{o}$ en el resguardo de un interés socialmente relevante (Montt, 2010: 7). Desde este punto de vista, entonces, también se presentan desiguales el administrativo sancionador y el derecho penal, puesto que no sólo los fines u objetivos de protección son desiguales, sino que la construcción normativa de la infracción penal, como de la infracción administrativa igualmente difiere.

130. Sentencia del Tribunal Constitucional rol 480-2006, considerando décimo.

131. El estándar del principio de culpabilidad en criterio del Tribunal Constitucional chileno. Véase la sentencia rol 2.744-2014, que reflexiona: «Que siendo el principio de culpabilidad uno de los pilares fundamentales del derecho penal actual, esto es un reflejo de la dignidad humana, reconocida en el artículo 1 de la Constitución, donde los factores subjetivos del delito se manifiestan en el ilícito, de forma tal que la exigencia de una imputación penal y la intención o culpabilidad propiamente tal deben estar insertas en la conducta desarrollada por el sujeto activo del injusto» (considerando trigésimo primero).

132. En similar sentido, Binding: «El tipo objetivo se convierte en el delito mismo si se representa la voluntad de su autor transformada en culpabilidad. De este modo, el hecho antijurídico pasa a ser contrario a deber. A su caracterización como contradicción de la norma se suma el juicio de un comportamiento jurídicamente reprochable de su autor, respecto de la exigencia que el ordenamiento jurídico ha dirigido de manera precisa a él personalmente» (2009: 4-5). En Chile, véase Etcheberry (1999: 270 y ss.).

133. La sanción disciplinaria presentaría menores problemas que la gubernativa propiamente tal. Según Cárcamo: «en derecho administrativo sancionador disciplinario, el escenario que se presenta es sustancialmente diferente, toda vez que existe un catálogo de principios rectores bastante más depurado» (2014: 151). Por ejemplo, el Estatuto Administrativo para Funcionarios de la Ley 18.834, como también el Estatuto Administrativo para Funcionarios Municipales, de la Ley 18.883.

134. Bermúdez tiene un enfoque similar: «En materia penal se relaciona la culpabilidad con la reprochabilidad, ya que se trata de un reproche con fundamento ético o moral, basado en la libertad de voluntad o libre albedrío, que le permite al sujeto comportarse o no conforme a derecho. En consecuencia, la culpabilidad en materia penal supone una actuación dolosa o culpable. La infracción administrativa, a diferencia de lo que ocurre en el ámbito penal, no contiene reproche moral, sino que sólo representa un carácter preventivo, sin importar si existe o no un reproche ético, ya que en definitiva la finalidad del derecho administrativo sancionador es la intangibilidad del ordenamiento jurídico» (2012: 115). 


\section{El Caso Pollos y el regreso «a fojas cero» de la discusión en el ámbito constitucional ${ }^{135}$}

Utilizando la misma nomenclatura, diríamos más bien que la discusión se encuentra en otra instancia, quizás de mayor profundización. Hoy el foro jurídico discurre sobre los principios (penales o no) y garantías (fundamentales) para aplicar al interior del derecho administrativo sancionador, pero no sobre la inconstitucionalidad ${ }^{136} \mathrm{de} \mathrm{la}$ potestad sancionadora de la administración. Discutimos acerca de qué reglas deben -correctamente- emplearse en silencio del legislador, para resolver los conflictos de reclamación, ante una sanción de la administración impuesta al ciudadano. Debemos ser capaces de resolver qué principios lógicamente deben sustentar la facultad de sancionar de la administración, bajo un posmoderno Estado de Derecho. Tenemos que discutir - al menos- si entendemos que derecho penal y derecho administrativo sancionador son ramas distintas, cada una con sus propios fines y sistemas de resolución de conflictos, parece imperioso determinar el contenido de las reglas para el administrativo sancionatorio si la legislación nacional no ofrece ayuda manifiesta.

En este sentido, el Tribunal Constitucional en la causa rol 2.381, del año 2013, conoció del asunto ventilado por inaplicabilidad de las normas relativas a la absolución de posiciones de representantes legales de Pollos Ariztía, Agrosuper y Don Pollo. Todo aquello en el marco de un proceso sancionatorio llevado a cabo ante el Tribunal de la Libre Competecia, en el cual la Fiscalía Nacional Económica acusó a estas empresas de haberse coludido para fijar las cantidades de pollo a vender en el mercado chileno. Este pronunciamiento decidió que era inaplicable a este proceso la garantía del derecho a no autoincriminarse ${ }^{137}$ en un procedimiento jurisdiccional de orden infraccional, ${ }^{138}$ dado que por muy cuantioso que fuere esta garantía procesal

135. La expresión está tomada de Rodríguez Collao (1987: 544).

136. Debate que hasta hace poco tiempo colmaba las letras de nuestros autores. Véase Soto Kloss (2005: 76- 88; 1979-1980: 95-103), Aróstica (1987: 71-81), Cárcamo (2014: 7-18) y Román (2008: 107-137).

137. Ríos y Ortiz (2011: 85) efectúan una sólida crítica a la tesis mayoritaria de la doctrina y jurisprudencia nacional, en torno a la tributación de las ganancias ilícitas para el imputado: «Es esta posición desfavorable la que debe enfrentar el imputado por cualquiera de los delitos que han generado una ganancia ilícita proveniente de la comisión de un delito - entendido a la luz de la jurisprudencia y doctrina mayoritaria de nuestro país - toda vez que estas ganancias van aparejadas de un delito base: auto acusarse, perjurio o desacato, son las alternativas disponibles. La interpretación jurisprudencial y doctrinaria ha resuelto esta situación a favor de la normativa legal-tributaria, pasando por alto absolutamente los alcances del principio del nemo tenetur» (p. 92-93).

138. «No parece posible considerar la obligación de declarar bajo juramento como una medida de coacción. Se trata de una exigencia dirigida a obtener la leal colaboración de terceros y partes en el ejercicio de la función jurisdiccional que corresponde al Estado y que busca sumar al proceso antecedentes fidedignos que completen el conocimiento de la cuestión debatida para su debida resolución. No puede estimarse que la obligación de decir verdad constituya un apremio ilegítimo», considerando vigésimo 
está exclusivamente reservada para el ámbito penal. ${ }^{139}$

El máximo garante de la Constitución sostuvo que la garantía a no autoincriminarse está contenida en el artículo 19, número 7, letra f) de la Carta Fundamental, pues ella de modo ostensible, y con un propósito claro, se refiere sólo a las «causas criminales». ${ }^{140}$ Entonces es plausible aseverar que existirían ciertas hipótesis en las que correspondería denegar la extrapolación de alguna clase de garantía, en atención a la naturaleza del procedimiento infraccional de la Libre Competencia. En la especie, el requerimiento de la Fiscalía Nacional Económica para acusar de colusión a las empresas citadas no era pertinente con respecto a la aplicación de la garantía a no autoincriminarse por estar disponible exclusivamente para los procedimientos del ámbito penal. Por tales razones, se argumenta que la discusión regresó a fojas cero. Debido a que la decisión del Tribunal Constitucional responde a que en atención a la diferencia de procedimiento (jurisdiccional de índole infraccional), ventilado en el Tribunal de la Libre Competencia, habría una diferencia de aplicación de garantías procesales a un procedimiento jurisdiccional, pero infraccional. ${ }^{141}$ En otras palabras, la magistratura constitucional advirtió que en el procedimiento sustanciado ante un tribunal, como el Tribunal de la Libre Competencia, no hay ejercicio alguno de la potestad de castigo. No existe en su vertiente penal, ni en su vertiente administrativasancionatoria. Vale decir, este proceso judicial: «se somete al régimen de garantías de procedimiento generales y no a las que la doctrina discute debiesen aplicarse en el ejercicio del derecho administrativo sancionador". ${ }^{142}$

En definitiva no se aplicó la garantía a no autoincriminarse al procedimiento sancionatorio sustanciado en el mentado tribunal jurídico-económico. Aquella garantía estaría reservada solo para los procedimientos de mayor gravedad (criminales), en que realmente se ejerza una actividad de castigo por parte del aparataje estatal (ius puniendi). Así, en esta clase de litigios la absolución de posiciones del gerente general no sería atentatoria contra el debido proceso en la garantía a no declarar contra sí mismo.

octavo de la sentencia del Tribunal Constitucional, rol 2.381-12, del año 2013.

139. En considerando decimoséptimo, tal pronunciamiento expresa que: «En consecuencia, el H. Tribunal de Defensa de la Libre Competencia, al ejercer una función jurisdiccional, se somete al régimen de garantías de procedimiento generales y no a las que la doctrina discute debiesen aplicarse en el ejercicio del derecho administrativo sancionador».

140. Sentencia del Tribunal Constitucional rol 2.381-12, año 2013, considerando undécimo.

141. «El constituyente, sin duda, ha querido reconocer esta garantía en un procedimiento en particular y no como una garantía general de todo procedimiento, pues éstas se encuentran en el numeral 3 del artículo 19", en sentencia del Tribunal Constitucional rol 2.381-12, año 2013, considerando décimo.

142. Considerando decimoséptimo, sentencia del Tribunal Constitucional rol 2.381-12, año 2013. 


\section{El caso Guzmán Lyon: Principio de proporcionalidad ${ }^{143}$ como eje del derecho administrativo sancionador}

Sabido es que el principio de proporcionalidad tiene su arranque en la jurisprudencia alemana ${ }^{144}$ con motivo del análisis entre el delito y pena, sin perjuicio de ser aplicado transversalmente también hoy en el ámbito administrativo. ${ }^{145}$ De forma reciente, el Tribunal Constitucional tuvo ocasión de conocer sobre el caso Guzmán Lyon con la Superintendencia de Valores y Seguros. ${ }^{146}$ El litigio ventiló la solicitud de inaplicabilidad del artículo 29 del Decreto Ley $3.538^{147}$ en la gestión judicial constituida por la reclamación de multa seguida ante un Juzgado Civil de Santiago. ${ }^{148}$ Este fallo se hace cargo de principios como igualdad ante la ley, así como de la garantía del debido proceso, ${ }^{149}$ entre otros. En lo que nos interesa se abordará lo relacionado con el principio de proporcionalidad y cómo éste sirvió para resolver la inaplicabilidad del precepto dado que la sanción resultaba — a juicio del tribunal— desproporcionada.

El quantum sancionatorio alcanzó las 550 mil Unidades de Fomento que excede en un $733 \%$ la multa máxima aplicable a la pluralidad de actos ilícitos ascendente a

143. No suele cuestionarse las garantías procedimentales en los procedimientos ante el Juzgado de Policía Local, al parecer por ser sustanciados ante un tribunal propiamente tal y generalmente por el escaso monto de las multas. No obstante, véase la contravención al principio de proporcionalidad en la sanción de un Juez de Policía Local, en sentencia del Tribunal Constitucional rol 2.045-2011.

144. «Su origen está en el derecho prusiano de policía, en donde la proporcionalidad cumplía una función orientativa respecto de las intervenciones en la libertad individual. La jurisprudencia del Tribunal Superior Administrativo de Prusia (preussisches OVG) sostuvo que este principio era vinculante para el poder ejecutivo, para lo cual acuñó el concepto de 'prohibición de exceso', como un criterio de control sobre los poderes discrecionales de la administración y como límite al ejercicio del poder de policía» (Rainer, Martínez y Zúñiga, 2012: 66).

145. En el horizonte norteamericano, véase Castiñeira y Ragués (2010: 257-295).

146. Sentencia del Tribunal Constitucional rol 2.922-2015, del 29 de septiembre de 2016. De manera reciente, en relación a la desproporción de la norma que obliga a cumplir presidio efectivo durante un año en contexto de la denominada «Ley Emilia», véase la sentencia del Tribunal Constitucional rol 3358-2016.

147. La norma en comento dispone que: «No obstante lo expresado en los artículos 27 y 28 al aplicar una multa, la Superintendencia, a su elección, podrá fijar su monto de acuerdo a los límites en ellos establecidos o hasta en un $30 \%$ del valor de la emisión u operación irregular. Para los efectos de los artículos precitados se entenderá que hay reiteración cuando se cometan dos o más infracciones, entre las cuales no medie un período superior a doce meses».

148. La gestión pendiente para recurrir de inaplicabilidad se ventilaba ante el $16 .^{\circ}$ Juzgado Civil de Santiago, rol de causa 21.305-2014.

149. Para estar en presencia de un debido proceso, la jurisprudencia ha entendido que debe existir algo más que la simple discreción en la imposición de la multa, véase la sentencia de la Corte Suprema rol 5.937-2008. Y el considerando decimosexto de la sentencia del Tribunal Constitucional rol 2.9222015, del 29 de septiembre de 2016. 
75.00o Unidades de Fomento, según el artículo 28 del mentado Decreto Ley. Para ello, la SVS hizo uso del artículo 29 del cuerpo legal referido.

La magistratura constitucional pone de manifiesto que desde hace algún tiempo ${ }^{150}$ el principio de proporcionalidad (Cárcamo, 2014: 149-165), ,51_-152 la «máxima de razonabilidad ${ }^{153} \mathrm{o}$ "principio de prohibición de exceso» ha fungido como elemento determinante para evaluar el equilibrio entre conducta y sanción atribuida. Como decíamos, el principio de proporcionalidad ${ }^{154}$ surgió a raíz de la imposición de sanciones penales. Así, este principio se formuló como «regla del derecho penal en los orígenes modernos de éste» (García de Enterría y Fernández, 2002: 177).

Es necesario exponer que antes del fallo, el test de proporcionalidad está compuesto de tres subprincipios. El primero es de adecuación, el segundo de necesidad y el tercero de proporcionalidad en sentido estricto. Cabe tener presente y recordar que los derechos fundamentales son mandatos de optimización. Lo anterior quiere decir que son normas de principio que ordenan la realización de algo en la más alta medida (Alexy, 2009: 8). De este modo Alexy precisa que: «adecuación y necesidad se tratan de una optimización relativa a posibilidades materiales». ${ }^{155}$ Dicho esto, el Tribunal Constitucional manifiesta que «la relación o vínculo entre el incumplimiento y la sanción que le sigue debe ser predecible, en tanto permite al sujeto obligado identificar sus obligaciones en una gradación acorde con los propósitos perseguidos por el ordenamiento jurídico». ${ }^{156}$

En el caso concreto, fue capital deliberar la razón de que proporcionalidad era «el nudo del dilema» a solucionar. Esto es, si en este caso en específico el inciso primero del artículo 29 del Decreto Ley 3.538, de 1980, tuvo o podría tener efectos contrarios a la Carta Fundamental. El Decreto Ley consagra la facultad para la autoridad administrativa de emplear:

150. Así se lee en considerando decimonoveno de la sentencia del Tribunal Constitucional rol 2.922-2015. 151. Sobre este principio la literatura es abundante; véase Alexy (2009: 3-13). Acerca de la restricción esencial frente a la superposición de derechos fundamentales, Alexy (1993: 267-286).

152. Para las objeciones a la formulación teórica del test de proporcionalidad, advirtiendo los nocivos efectos que su aplicación habitual trae aparejada para la tutela de los derechos fundamentales en caso de emplearse la noción consecuencialista del aludido test, véase Covarrubias (2012).

153. Para un análisis del principio de razonabilidad en criterio del Tribunal Constitucional, véase Martínez y Zúñiga (2011: 199-226).

154. En tal sentido, Cárcamo defiendo acertadamente: «Pues bien, en la actualidad, precisamente, uno de los principios más relevantes que vincula a la Administración del Estado en el ejercicio de sus poderes punitivos, es el principio de proporcionalidad de la sanción, principio conforme al cual, siempre debe existir una razonable adecuación entre el desvalor o naturaleza del ilícito cometido y la sanción que se aplica al autor del mismo» (2014: 154-155).

155. Sobre el contenido de cada subprincipio nos remitimos a lo señalado por Alexy (2009: 8). Para objeciones a la tesis, Covarrubias (2012: 447-48o).

156. Sentencia del Tribunal Constitucional rol 2.922-2015, considerando trigésimo segundo. 
i) Las reglas establecidas en los artículos 27 y 28 del Decreto Ley 3.538 (con la opción de la imposición de una multa de UF 15.00o, que puede aumentarse cinco veces en caso de infracciones reiteradas); o

ii) La regla genérica contemplada en el artículo 29, que alude a la multa del $30 \%$ del valor de la emisión u operación irregular.

El problema fue, en suma, «referente al carácter razonable o proporcional estricto de la medida, resulta a todas luces evidente que la norma cuestionada no fija parámetro alguno o baremo objetivo a considerar para singularizar el monto de la multa». ${ }^{157}$ El tribunal insistió en la inexistencia de criterios objetivos o razonables que determinen la forma en que corresponda aplicar la sanción prevista en este artículo 29. En este orden de ideas, el Tribunal Constitucional entendió que la disposición cuestionada no fija parámetro alguno de razonabilidad a la autoridad, lo que no se compadece con criterios mínimos de proporcionalidad reiterados en su jurisprudencia. ${ }^{158}$ En fin, se tendrá como razonamiento para acoger la acción de inaplicabilidad en este fallo que no hay realmente ningún parámetro de «objetividad» ${ }^{159}$ para la aplicación del artículo 29. Lo ya expuesto, desde que se hace una mera remisión también general y no motivada a lo dispuesto en el artículo 27 y 28 del mencionado Decreto Ley. Este último relativo al evento de que existe una multiplicidad de hechos infraccionales, con un tope de UF 75.000 ( 5 veces la sanción de UF 15.000).

La aplicación del precepto cuestionado produce en el caso concreto efectos contrarios a la Constitución, específicamente al principio de proporcionalidad. En palabras del Tribunal Constitucional, «desde que su materialización fáctica no se sustenta sobre la base de criterios de razonabilidad (objetivos y ponderados) que permitan determinar por qué se ha impuesto una determinada sanción e incluso por qué un porcentaje especifico y no otro». ${ }^{160}$

157. Sentencia del Tribunal Constitucional rol 2.922-2015, considerando trigésimo noveno.

158. Sentencia del Tribunal Constitucional rol 2.922-2015, considerando cuadragésimo quinto. En relación al principio de proporcionalidad en el Tribunal Constitucional, cf. Rainer, Martínez y Zúñiga (2012: 65-116).

159. Véase otra tesis en la disidencia de los ministros del fallo, p. 104 y ss.

16o. Sentencia del Tribunal Constitucional rol 2.922-2015, considerando cuadragésimo noveno, que precisa: «La disposición legal impugnada impone de esta manera una potestad discrecional arbitraria que no se compadece con las exigencias mínimas de un Estado de Derecho, que permitan fundamentar la decisión, y luego de una detallada subsunción de los hechos al derecho, señalar de manera lógica y precisa cuál es la razón del quantum de la sanción, cumpliendo así con los presupuestos de un debido proceso administrativo». La opinión minoritaria del recurso, cree que la multa aplicada pasa el test de proporcionalidad, p. 104: «el juez constitucional debe ponderar los bienes jurídicos y derechos en juego, según las circunstancias del caso concreto, y determinar si el sacrificio de los intereses individuales guarda una relación razonable y proporcionada con la importancia del interés estatal a salvaguardar». 


\section{Corolario: Una comprensión alternativa de la potestad sancionadora administrativa}

De conformidad a lo que se ha exhibido, nuestro foro jurídico asigna los principios limitadores de la potestad punitiva del Estado a las sanciones administrativas, pero con «matices». ${ }^{161} \mathrm{El}$ problema que detectamos y mantiene en suspenso la interrogante, como podrá compartir el lector, es en qué consisten tales matices. ${ }^{162}$

Lo previamente expuesto, como hemos insistido, es resultado de la concepción que la magistratura constitucional y judicial conserva sobre la potestad sancionadora de la Administración Pública, en donde casos análogos han presentado soluciones disparejas, por lo que acertar sobre las garantías del procedimiento resulta para el eventual administrado, por ahora, difícil. Algo es seguro, los matices obedecen a las características propias del derecho administrativo sancionador. De este modo, las garantías del debido proceso le son ajustables. Con todo, un entendimiento correcto de la potestad sancionadora de la Administración, es decir, que el objeto de esta potestad es regular y no sancionar, al menos no en clave de derecho penal, permite clarificar el panorama. La prueba se encuentra en los criterios de eficiencia distintos a los perseguidos por el derecho penal. Esto quiere mostrar en simple que el derecho administrativo sancionador regula y no «castiga». Sin embargo, como toda actividad de la Administración debe enmarcarse dentro de los principios que informan ese actuar. En consecuencia, al administrado le asisten garantías diversas, ${ }^{163}$ pero que permiten su seguridad y respeto al debido proceso. A los eventuales sancionados le asisten garantías a un debido proceso por el solo hecho de su calidad de personas, pero primordialmente por el hecho de estar siendo objeto de un procedimiento - de sanción - por un órgano de la Administración estatal, mas no porque el servicio público que incoa tal procedimiento esté ejerciendo el cuestionado ius puniendi estatal. Máxime que como tal debe respetar los contenidos mínimos de un debido proceso, antes mejor que cualquier otro órgano de la sociedad. El asunto pasa por consensuar que la sanción administrativa no es una pena. Los argumentos que se pueden dar al efecto son varios y variados. Existen, entre otros, los siguientes que deseamos sistematizar al final de estas líneas.

161. Sentencia del Tribunal Constitucional rol 747-2007, considerando vigésimo segundo, Caso Kokisch, sentencia del Tribunal Constitucional rol 1.518-2009, considerandos sexto y vigésimo cuarto.

162. En similar pensamiento y crítico frente a la teoría de las garantías penales al administrativo sancionatorio, y por ende que la multa, en el procedimiento administrativo sancionador, es transmisible para los herederos, desde su notificación, véase Letelier (2015: 319, 329). En misma línea, véase la sentencia de la Corte Suprema rol 1079-2014, Caso Mackenna, considerando undécimo.

163. Así se ha expresado: «las garantías del derecho sancionatorio administrativo (indispensables ante toda privación o restricción de derechos) pueden ser similares o aproximadas a las garantías propias del derecho penal, pero que no son ni deben ser las mismas que las del derecho penal, incluso si se asumen la tesis de que entre ambos órdenes media sólo una diferencia cuantitativa» (Hernández, 2014: 568, nota 2). 


\section{Argumento teleológico}

De la manera ya explicada más arriba este argumento atiende a los fines que cada rama del ordenamiento jurídico tiene. El objetivo que tiene la potestad administrativa de sanción - vale decir el derecho administrativo sancionador- no encuentra (y no puede encontrar) su fundamento en una de las así llamadas teorías de la justificación de la pena.

\section{Argumento pragmático}

Este argumento es posible de resumir en: el adecuado entendimiento del sistema social a regular por el derecho administrativo. Por regla general, las superintendencias, sea cual sea, son creadas para «fiscalizar» un área que requiere regulación. Esto es, para ordenar el cumplimiento de su actividad y la protección del interés socialmente relevante que el legislador le ha designado.

\section{La falacia del ius puniendi ${ }^{164}$}

Como creemos haber demostrado, no es necesario incurrir en la falacia que supone argüir que el derecho administrativo sancionador se inserta dentro del derecho subjetivo del Estado a castigar, para así otorgar garantías a los administrados. Por el contrario, una reflexión profunda, funcional y prolija del tema permite observar como una incipiente jurisprudencia ${ }^{165}$ consigue consentir las garantías adecuadas dentro del procedimiento sin necesidad de recurrir a meras referencias a principios. Además, probado está el rendimiento insuficiente tanto de la teoría de la diferencia cualitativa (García Cavero, 2016: 26), ${ }^{166}$ como de la teoría de la diferencia cuantitativa. Igualmente continuar propugnado la tesis del ius puniendi produce que los administrados desconozcan acorde a qué principios y/o garantías deberán atenerse en uno u

164. En contra de la tesis del ius puniendi, entre otros, Cid (1996); Román (2008: 138; Zúñiga (2015: 141). Por su parte también Mañalich (2014: 544). García Cavero (2016: 26) sin pronunciarse explícitamente en contra, aboga por una relación funcional entre la sanción administrativa y la pena, conforme al efecto comunicativo que debe expresar la actuación contraria a derecho.

165. Pese a que se encuentra un tanto forzado recurso de queja en su contra, el fallo constituye un alentador precedente, ya que no necesita utilizar la tesis del ius puniendi para arbitrar al sancionado de la «macro» garantía al debido proceso. SCA rol No 644-2016. De cierta forma también se aprecia en sentencia del Tribunal Constitucional rol No 2.922-2016.

166. Sobre aquella teoría: «(...) lo que la sanción administrativa procura es asegurar el adecuado funcionamiento de los sectores sociales sometidos a regulación. Esta diferencia de fundamento explicaría los distintos criterios de imputación que se manejan en el ámbito penal en relación con los propios del Derecho administrativo sancionador» 
otro supuestos de derecho administrativo sancionador. ${ }^{167}$ Así puede verse en el caso Pollos (en que se negó una garantía por estar «reservada» para el ámbito penal); o bien en caso Corpbanca (en que la Administración creyó autorizado su accionar y advirtió frustrado su proceder), ya sea en el criterio de proporcionalidad que ocupó novedosamente para estas hipótesis el Tribunal Constitucional.

Interesante es subrayar que en el caso Corpbanca no se hace mayor alusión a la tesis del ius puniendi del Estado para otorgar las garantías (debido proceso) que asisten a los administrados de cara a un procedimiento administrativo sancionatorio. Inexcusablemente no debe buscarse en la supuesta y harto magnificada tesis del ius puniendi la respuesta al otorgamiento de garantías mínimas del ciudadano frente a la Administración. La Administración Pública paradigmáticamente se encuentra sujeta al principio de legalidad y sujeta a responsabilidad de actuar fuera del ámbito de su competencia. Conjuntamente desde la posición del sujeto que se encuentra en un procedimiento de sanción, le asisten también un mínimo de garantías. Lo anterior no es porque la Administración del Estado lo esté juzgando penalmente. Y es que un procedimiento carente de garantías mínimas atenta contra un elemental derecho humano ${ }^{168}$ que asiste a las personas naturales por el hecho de ser tales.

Así también el argumento precedente ha sido utilizado por la Corte Interamericana de Derechos Humanos para definir su postura frente a la potestad sancionadora de la Administración. Al efecto, ha indicado que ambas sanciones: «Unas y otras implican menoscabo, privación o alteración de los derechos de las personas, como consecuencia de una conducta ilícita. Por lo tanto, en un sistema democrático es preciso extremar las precauciones para que dichas medidas se adopten con estricto respeto a los derechos básicos de las personas y previa una cuidadosa verificación de la efectiva existencia de la conducta ilícita.» ${ }^{169}$ De esta manera, ya no es preocupante que la función administrativa de sanción se pueda desnaturalizar por utilización de garantías penales. En este contexto, el derecho administrativo sancionador tiene sus propios principios que si bien en su forma pueden ser similares a los del derecho penal, en el fondo asumen su propia esencia.

167. Así quedó demostrado con el caso Pollos, sentencia del Tribunal Constitucional rol 2.381-12.

168. «El ejercicio de la soberanía reconoce como limitación el respeto a los derechos esenciales que emanan de la naturaleza humana», artículo 5, inciso segundo de la Constitución. En cierto sentido también el artículo 19 número 26 de la Carta Política.

169. Así en Corte Interamericana de Derechos Humanos, en el caso Baena Ricardo y otros contra el Estado de Panamá, punto 106, pp. 84-85. Disponible en http://www.oas.org/es/cidh/. 


\section{La Administración contempla herramientas diversas y baraja un ámbito técnico ${ }^{170}$ que el adjudicador jurídico ${ }^{171}$ generalmente desconoce ${ }^{172}$}

Si se comparte que la función del derecho administrativo sancionador es primero regular o reglar bajo criterios de eficiencia y protección del interés salvaguardado y que para ello posee diversos instrumentos (mejores que los del juez), es posible también otorgar garantías que no desnaturalicen esta valiosa función de la Administración. Bajo este razonamiento, la potestad sancionadora de la Administración no debe ocuparse de «castigar» todas y cada una de las conductas. Más bien esta potestad, en caso de tener que ordenar el sistema asignado, puede sancionar pero también maneja otras herramientas previas a la multa. De esta forma se evita sancionar conductas innecesarias ${ }^{173}$ que puedan subsanarse por medio de instrumentos que revistan mayor eficiencia que una multa. Por ejemplo, en el caso de que alguien por mero descuido usa un vertedero ilegal de residuos, la Administración podría ordenar al infractor detener tales faenas ${ }^{174}$ antes que la imposición de una cuantiosa multa. ${ }^{175}$ Pues bien, si la Administración Pública funcionara mediante la lógica de herramientas prima ratio -que son sus herramientas- no sería necesario esgrimir el constante «auxilio» de garantías propiamente penales, que suele defenderse en estas contiendas. Suficiente sería aludir a las garantías propias del derecho administrativo sancionador. Además,

170. «La Administración no solo tiene más conocimiento técnico que los jueces, sino también mayor legitimidad democrática, especialmente en un país presidencialista como el nuestro» (Montt, 2006: 8).

171. Londoño (2014: 147-167) sostiene la conveniencia de distinguir entre tipicidad penal estricta y tipicidad en el derecho administrativo sancionatorio, que puede ser más laxa. En síntesis, se plantea que los jueces parecen comportarse como adecuados aplicadores de reglas estrictas, en espacios de relativa comodidad hermenéutica (por formación y tradición). Su rendimiento puede en cambio verse mermado allí donde se trate de estándares, operativos en sectores complejos, dinámicos y tendencialmente lejanos a su quehacer habitual. Como lo constituyen paradigmáticamente los sectores económicos y financieros (2014: 166).

172. Así el famoso caso Chevron U.S.A., Inc. v. Natural Resources Defense Council, 467 US 837, 865-866 (1984).

173. Desde la identificación del interés relevante que protege la norma, para su interpretación proporcionada y no dar lugar a sanciones innecesarias, véase García (2013).

174. Cf. el inciso segundo del artículo 174 del Código Sanitario: «Las infracciones antes señaladas podrán ser sancionadas, además, con la clausura de establecimientos, recintos, edificios, casas, locales o lugares de trabajo donde se cometiere la infracción; con la cancelación de la autorización de funcionamiento o de los permisos concedidos; con la paralización de obras o faenas; con la suspensión de la distribución y uso de los productos de que se trate, y con el retiro, decomiso, destrucción o desnaturalización de los mismos, cuando proceda».

175. «Salvo las disposiciones que tengan una sanción especial, será castigada con multa de un décimo de Unidad Tributaria Mensual hasta mil Unidades Tributarias Mensuales. Las reincidencias podrán ser sancionadas hasta con el doble de la multa original»: así reza el inciso primero del artículo 174 del Código Sanitario. 
que en la imposición de la sanción administrativa se debe respetar la proporcionalidad no por estar castigando al regulado, sino por ser un principio que es transversal al ordenamiento y que es necesario como criterio rector para la actividad estatal.

\section{El acto administrativo de sanción debe ser especialmente fundado}

Como abono a lo planteado se debe recordar que la sanción administrativa es caracterizada por algunos como un acto de gravamen, pese a que la sanción es reaccional y no se debe confundir con actos de gravamen propiamente tales, aunque es una tipología de ellos (Cordero Vega, 2015: 495-496). En este marco conceptual, el acto administrativo por medio del cual se impone la sanción — sea cual fuese- debe ser un acto especialmente motivado. En efecto, se ha expresado que «los actos de gravamen están sujetos a mayores exigencias desde el principio de legalidad (la incidencia negativa en la esfera del particular debe tener suficiente cobertura de norma con rango legal formal) que el de los actos favorables» (Cordero Vega, 2015: 495). En concreto, esto supone en primer término que los actos de gravamen (desfavorable o limitativo de derechos) conforman aquel grupo respecto del cual la Ley de Bases de Procedimientos Administrativos exige indefectiblemente una especial motivación. ${ }^{176}$ En segundo término, que los actos favorables o declaratorios de derechos quedan sujetos al principio de irrevocabilidad, lo que no sucede con el acto de gravamen. En tercer término, por lo general es que los actos administrativos no tendrán efecto retroactivo, salvo cuando su retroactividad produzca efectos favorables a los interesados, lo cual se aplica rigurosamente a los actos de gravamen.

\section{Conclusiones: La imperiosa necesidad de una regulación al administrativo sancionatorio en Chile}

Como se puede observar, en la especie urge una regulación sistemática y orgánica, ya sea una ley que ordene los principios aplicables al derecho administrativo sancionador, ${ }^{177}$ como su procedimiento. $\mathrm{O}$ bien, una modificación orgánica que detalle expresamente los fines de cada agencia y sus herramientas de manera responsiva $\mathrm{o}$, por lo menos, en forma prima ratio. Al parecer, en la vorágine de la clase política por dictar leyes y la supuesta efectividad ${ }^{178}$ de reglar la conducta humana sólo mediante

\footnotetext{
176. Artículo 11, inciso segundo, Ley 19.880; artículo 61, letra a), Ley 19.880 y el artículo 52 de la Ley 19.880.

177. Vacío legal que no fue subsanado en Proyecto de Ley de Bases de los Procedimientos Administrativos Sancionatorios, iniciado por Mensaje 541-350, de 25 de marzo de 2004 (Boletín 3475-06). Hoy se encuentra archivado.

178. Acerca de los delitos empresariales, su impunidad en Chile, y de cómo dicha exigencia social refleja características del sistema penal chileno, puede verse Winter (2013). Desde el horizonte comparado,
} 
ellas, se extraña un cuerpo sistematizado que atienda el vacío normativo que la jurisprudencia ha debido colmar.

Justamente para tal cometido debemos reflexionar sobre la naturaleza del sector social que los técnicos de la Administración Pública ordenan día a día. Así, se debe pensar que las facultades y expertise que poseen ciertas agencias del Estado permiten un movimiento mucho más laxo, dentro del ámbito de su competencia que el que posee el juez (Londoño, 2015: 165-166) ) $^{179}$ para la resolución de conflictos. Naturalmente existen principios y garantías en estos procesos, empero no porque exista una identidad ontológica entre la sanción penal y la administrativa; o bien porque el derecho administrativo sancionador sea una manifestación más del ius puniendi. La Administración estatal encuentra su límite (necesariamente) en el derecho que asiste a toda persona - por ser inherente a ella- un debido proceso. ${ }^{180}$ Conjuntamente y como es de usual conocimiento, la Administración Pública no cuenta con «apoderamientos en blanco» (Bermúdez, 2008: 108). Es el principio de legalidad el que dota de contenido el actuar del poder sancionatorio y lo dirige. Lo medular, como hemos destacado, es que esos fines u objetivos existan en la ley que da competencia al servicio en cuestión.

La discusión, como intentamos describir, no está en modo alguno clausurada. El péndulo jurisprudencial chileno no ha terminado de oscilar. Al contrario, nos vemos enfrentados a un escenario prometedor. Eso sí, en lo relativo a las garantías que (por las razones correctas) debiesen ordenar e informar al derecho administrativo sancionador. Máxime, como un connotado autor alemán expresa sobre la limitada capacidad del derecho para solucionar: «de forma absoluta los conflictos [...] para los que fue creado, sino sólo los conflictos que es capaz de construir por sí mismo». ${ }^{181}$

En consecuencia, un entendimiento racional y correcto de las reglas jurídicas de nuestro sistema permite construir a la potestad administrativa sancionatoria como una herramienta (privilegiada) de regulación. Desde este lugar, entonces, se entiende por un lado que no todas las hipótesis ameriten ser sancionadas. Por su parte, las garantías que integren tales procedimientos serán distintas a las de un procedimiento penal, puesto que no se está castigando en uso del ius puniendi estatal.

\section{Hassemer (1995: 23-36).}

179. Tiedemann anota que existe una ventaja de las sanciones administrativas en el ámbito de la criminalidad económica, ya que «la Administración profesional, en todo caso, está capacitada técnicamente y para la rápida tramitación de los asuntos. Esta ventaja se opone, a veces, al inconveniente de que esta clase de sanciones no son impuestas de forma pública» (1993: 230-231).

180. Considerando quinto de la sentencia de la Corte de Apelaciones rol 644-2016, que expresa que «[el] Constituyente entendió sobre ello que no bastaba la exigencia del proceso legal porque 'debido' no se corresponde necesariamente con lo que dice la ley».

181. Niklas Luhmann, Das Recht der Gesellschaft, 1993, p.159, citado por Müller-Tuckfeld (2000: 526-527). 
Con todo, si se quiere defender que la sanción administrativa se enmarca en nuestro país, efectivamente, dentro de la actividad punitiva del Estado, que se haga y se emprenda ese rumbo. Pero lo deseable sería que esa dogmática se defienda con la normativa existente en Chile y con nuestras reglas. ${ }^{182}$ Con esto se quiere decir que debe efectuarse dogmática con las normas que tiene Chile vigente y no con las que carece, ya que como se hizo mención con la tesis española (que en Chile se intentó imitar) parte de una base normativa constitucional.

En consecuencia, y esperando no resultar reiterativo, creemos debe reglarse, mediante una ley dedicada especialmente a ello, el procedimiento sancionatorio administrativo, por medio del cual se ejerce la potestad administrativa sancionatoria. $\mathrm{Y}$ como esperamos quedó probado, una herramienta de regulación (social) tan valiosa como la sanción administrativa no puede resultar satisfecha con la mera existencia de la sistemática consagrada en la Ley 19.880 .

\section{Referencias}

AlCalde Rodríguez, Enrique (2009). «Algunas consideraciones en torno a la identidad sustancial entre la sanción penal y la pena administrativa». En Jaime Arancibia Mattar y José Ignacio Martínez Estay, La primacía de la persona. Santiago: Legal Publishing.

-. (2011). «Aplicación de los principios de tipicidad, culpabilidad y proporcionalidad en la infracción administrativa». Actualidad Jurídica (Universidad del Desarrollo), 24 .

Alexy, Robert (2009). «Derechos fundamentales, ponderación y racionalidad». Revista Iberoamericana de Derecho Procesal Constitucional, 11: 3-13.

-. (1993). Teoría de los Derechos Fundamentales. Madrid: Centro de Estudios Constitucionales.

Arancibia MatTar, Jaime (2014). «El principio de necesidad como potestad de última ratio». En Jaime Arancibia y Pablo Alarcón (coordinadores), Sanciones administrativas (pp. 129-147). Santiago: Legal Publishing.

Aróstica Maldonado, Iván (1991). «¿Qué queda de la 'presunción de legalidad’?» Gaceta Jurídica, 134, 277.

-. (1986). «La motivación de los actos administrativos en el derecho chileno». Revista de Derecho de la Pontificia Universidad Católica de Valparaíso, 10: 499-520.

-. (2008). «Los contenciosos administrativos especiales en la legislación chilena. Una visión crítica a la luz de la constitución». Revista Ius Publicum, 20: 85-103.

-. (1987). «Algunos problemas del Derecho Administrativo Penal». Revista de Derecho (Universidad de Concepción), 182: 71-81.

182. Como se indicó, Chile carece de un símil al 25.1 de la Constitución Española. 
BArros Bourie, Enrique (2006). Tratado de Responsabilidad Extracontractual. Santiago: Jurídica.

BecCaria, Cesare (1995). Dei delitti e delle pene, publicada originalmente en Livorno, 1764, según la traducción De los delitos y de las penas, Alianza, Madrid.

Bermúdez Soto, Jorge (2012). Las relaciones entre el Derecho Administrativo y el Derecho Común. Santiago: Thomson Reuters.

-. (2013). «Fundamento y límites de la potestad sancionadora administrativa en materia ambiental». Revista de Derecho (Pontificia Universidad Católica de Valparaíso), 40: 421-447.

-. (2014). Derecho administrativo general. 3. ${ }^{a}$ Edición. Santiago: Thomson Reuters.

Binding, Karl (2009). La culpabilidad en Derecho Penal. Traducción de Manuel Cáncio Meliá. Buenos Aires: BdeF.

Braithwaite, John e Ian Ayres (1995). Responsive regulation. Transcending de deregulation debate. Nueva York: Oxford University Press.

CÁrCAmo Righetti, Alejandro (2014). «La obligatoria observancia del principio de proporcionalidad de la sanción en el derecho administrativo sancionador: Fundamentos, alcances y aplicaciones». En Sanciones Administrativas. X Jornadas de Derecho Administrativo, Asociación de Derecho Administrativo, Editorial Thomson Reuters, Santiago, pp. 149-165.

Castiñeira, María Teresa y Ramón Ragués (2010). «Three strikes and you are out: El principio de proporcionalidad en la jurisprudencia del Tribunal Supremo de los Estados Unidos». En Miguel Carbonell, El principio de proporcionalidad en la interpretación jurídica. Santiago: Librotecnia.

Cerezo Mir, José (1981). Curso de Derecho Penal español. Parte general. 2. ${ }^{a}$ edición. Madrid: Tecnos.

—. (1975). «Límites entre el derecho penal y el derecho administrativo». Anuario de Derecho Penal y Ciencias Penales. Tomo XXVIII, Fascículo II, mayo-agosto, pp. 159-173.

Cid Moliné, Josep (1996). «Garantías y sanciones (argumentos contra la tesis de la identidad de garantías entre las sanciones punitivas)». Revista de Administración Pública,140: 131-174.

Cordero Vega, Luis (2010). «El decaimiento del procedimiento administrativo sancionador. Comentarios a las sentencias de la Corte Suprema del año 2010». En Anuario de Derecho Público 2010 (UDP), pp. 243-255.

-. (2015). Lecciones de derecho administrativo. Santiago: Legal Publishing.

Cordero, Eduardo (2014). Derecho Administrativo Sancionador. Santiago: Legal Publishing/Thomson Reuters.

Cousiño, Luis (1975). Derecho Penal Chileno. Tomo I. Santiago: Jurídica.

Couso, Jaime y Héctor Hernández (2011). Código Penal Comentado. Libro Primero. Santiago: Abeledo Perrot. 
Covarrubias, Ignacio (2012). «La desproporción del test de proporcionalidad. Aspectos Problemáticos en su formulación y aplicación». Revista Chilena de Derecho, 39 (2): 447-480.

CuRY, Enrique (1979). «Algunas reflexiones sobre la relación entre penas penales y administrativas». Boletín de Investigaciones (U. Católica de Chile, Facultad de Derecho), 6 (44): 89 .

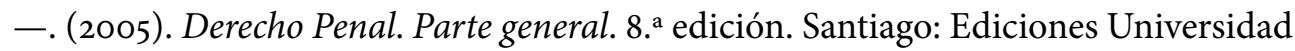
Católica de Chile.

-. (2008). Derecho Penal. Parte general. Santiago: Ediciones Universidad Católica de Chile.

De Palma del Teso, Ángeles (1996). El principio de culpabilidad en el derecho administrativo sancionador. Madrid: Tecnos.

DÍAZ DE VALDÉs, José Manuel (2010). «Anomalías constitucionales de las superintendencias: Un diagnóstico». Estudios Constitucionales (Centro de Estudios Constitucionales de la Universidad de Talca), 8 (1).

Etcheberry, Alfredo (1999). Derecho Penal. Tomo 1. Santiago: Jurídica.

FeIJóo SánCHEZ, Bernardo (2007). «Sobre la 'administrativización’ del derecho penal en la 'sociedad del riesgo'. Un apunte sobre la política criminal a principios del siglo XXI». Revista Derecho Penal Contemporáneo, 19.

Fermandois, Arturo y Jorge Baraona (2003). «La inexistencia de los hechos que fundamentan un acto administrativo ¿constituye un vicio de nulidad?». Revista de Derecho (Universidad Finis Terrae), 7: 79-103.

Ferrada Bórquez, Juan Carlos (2014). «La articulación de las potestades administrativas y jurisdiccionales en la aplicación de Sanciones Administrativas en el Derecho chileno: poderes distintos, pero complementarios». En Jaime Arancibia y Pablo Alarcón (coordinadores), Sanciones administrativas. Santiago: Legal Publishing-Universidad de Los Andes.

García Cavero, Percy (2016). «El principio del ne bis in ídem material en caso de concurrencia de pena y sanción administrativa», en Política Criminal. Vol. 11, $\mathrm{N}^{\circ}$ 21 (Julio 2016), Art. 2.

García De Enterría, Eduardo y Fernández, Tomas Ramón (2002). Curso de Derecho Administrativo II. Editorial Civitas. Octava Edición. Madrid, España.

García De ENTERría, Eduardo (1976). «El problema jurídico de las sanciones administrativas», en Revista Española de Derecho Administrativo, ( $\left.{ }^{\circ} 10\right)$, p. 409 y ss.

García Palominos, Gonzalo (2013). «Modelo de Protección en normas administrativas y penales que regulan el abuso de información privilegiada en la legislación chilena», en Política Criminal, volumen VIII, $\mathrm{N}^{\circ} 15$ (Julio 2013), pp. 23-63.

Garrido Montt, Mario (2001). Derecho Penal. Parte General. Tomo I. Editorial Jurídica, Santiago. 
Guzmán Dalbora, José Luis (2008). La pena y la extinción de la responsabilidad penal. Santiago, Legal Publishing, Santiago.

Guiloff, Matías y Soto, Pablo (2015). «Sanciones administrativas, discrecionalidad y revisión judicial: Una mirada desde la regulación responsiva», en Pinilla, Francisco; Bermúdez, Jorge y Ferrada, Juan Carlos: La nueva justicia ambiental. Editorial Thomson Reuters, Santiago de Chile.

Hassemer, Winfried (2007). «¿Puede haber delitos que no afecten a un bien jurídico penal?», en Hefendehl, Roland (ed.), La Teoría del Bien Jurídico, Marcial Pons, Madrid, pp. 95-104.

-. (1995). «Derecho Penal Simbólico y protección de Bienes Jurídicos», en: Pena y Estado, Editorial Jurídica Conosur, Santiago.

Hefendehl, Roland (2007). «El bien jurídico como eje material de la norma», en: Hefendehl, Roland (ed.): La Teoría del Bien Jurídico, Marcial Pons, Madrid, pp. 179-196.

Hernández Basualto, Héctor (2014). «Actividad Administrativa, Procedimiento Sancionatorio-Administrativo y Proceso Penal: Algunas necesidades de coordinación legal», en Sanciones Administrativas. Arancibia, Jaime y Alarcón, Pablo (coordinadores), Editorial Legal Publishing-Universidad de los Andes, Santiago, p. 568, nota $\mathrm{N}^{\circ} 2$.

Huergo Lora, Alejandro (1997). Las Sanciones Administrativas. 1era edición, Editorial Iustel, Madrid.

Јаковs, Günther (1997). Derecho penal. Parte general. Fundamentos y teoría de la imputación. $2^{\circ}$ edición, Marcial Pons, Madrid.

-. (2015). «Expectativas normativas», en: Polaino-Orts, Miguel (Coord.): El lado comunicativo y el lado silencioso del Derecho Penal, Ediciones del Centro, Lima.

JARA, Jaime y Maturana, Cristián (2009). «Acta de Fiscalización y Debido Procedimiento Administrativo», en Revista de Derecho Administrativo, $\mathrm{N}^{\circ}$ 3, vol. 5. (1-28).

Kindhauser, Urs y Mañalich, Juan Pablo (2011). Pena y Culpabilidad en el Estado Democrático de Derecho, Editorial BdeF, Montevideo- Buenos Aires.

Labatut Glena, Gustavo (1968). Derecho Penal. Editorial Jurídica, Santiago, Volumen 1.

Letelier Wartenberg, Raúl (2015). «La Ejecutoriedad de las Sanciones Administrativas, a propósito de la sentencia de la Corte Suprema en el Caso Mackenna», en Anuario de Derecho Público (UDP), Santiago de Chile.

-. (2014). «Garantías penales y sanciones administrativas. A propósito de la sentencia de la Corte Suprema en el llamado caso Mackenna», en Diario Constitucional, 5 noviembre 2014.

Londoño Martínez, Fernando (2014). «Tipicidad y legalidad en el derecho administrativo-sancionatorio», en Revista Derecho (Valdivia) [online], vol.27, n.2 [citado 2015-12-29], pp. 147-167. 
LóPEz LóPEz, Hugo (2009). El principio de culpabilidad en materia de infracciones tributarias. Thomson Reuters, Madrid.

MaÑalich, Juan Pablo (2014). «El principio ne bis in ídem frente a la superposición del derecho penal y el derecho administrativo sancionatorio» [en línea] en Política criminal, Diciembre 2014, volumen 9, número $18<$ www.políticacriminal.cl $>$ pp. 543-563. [consulta: 10 de septiembre de 2015].

-. (2015). «Retribucionismo consecuencialista como programa de ideología punitiva. Una defensa de la teoría de la retribución de Ernst Beling», Universidad de Chile, Santiago, Chile, Disponible en http://repositorio.uchile.cl. [Fecha consulta: 31 de diciembre 2015].

Martínez, José Ignacio y Zúñiga, Francisco (2011). «El Principio de Razonabilidad en la Jurisprudencia del Tribunal Constitucional», en Estudios Constitucionales, Año 9, No 1, pp. $199-226$.

Matus, Jean Pierre; Politoff, Sergio y Ramírez, Cecilia (2004). Lecciones de derecho penal chileno, Editorial Jurídica, Santiago.

Mendoza ZúñIgA, Ramiro (2006). «Acerca del Principio General de Intransmisibilidad de las Multas (en particular cuando ellas no se encuentran ejecutoriadas)», en Sanciones Administrativas y Derechos Fundamentales. Conferencias Santo Tomás de Aquino. Academia de Derecho Universidad Santo Tomás. Santiago, pp.127-153.

-. (2004). «Sanción Administrativa: Análisis a la luz de las garantías constitucionales» en Revista La Semana Jurídica. 1 a 7 de noviembre de 2004.

MerkL, Adolf (2004). Teoría General del Derecho Administrativo, Comares, Granada.

MontT, Santiago (2010). "Autonomía y responsividad: Dos expresiones de la vocación juridificadora del Derecho Administrativo y sus principios fundamentales», en Centro de Regulación y Competencia. Facultad de Derecho, Universidad de Chile.

Moraga Klenner, Claudio (2008). «Derecho Público Chileno y los principios de legalidad administrativa y de juridicidad», en Pantoja, Rolando (coord). Derecho Administrativo, 120 años de cátedra. Editorial Jurídica de Chile, Santiago.

Müller-Tuckfeld, Jens Christian (2000). «Ensayo para la abolición del Derecho Penal del Medio Ambiente», en La Insostenible situación del Derecho Penal, Editorial Comares, Granada.

Navarro Beltrán, Enrique (2014). «La potestad sancionadora administrativa y la jurisprudencia del Tribunal Constitucional», en Mattar, Jaime y Alarcón, Pablo (coordinadores), Sanciones Administrativas. Editorial Legal Publishing/ Universidad de los Andes, Santiago.

-. (2005). «Notas sobre Potestad Sancionatoria de la Autoridad Administrativa y Principio de Legalidad», en Revista de Derecho Público, (Nº67), pp. 118 y ss.

Nieto, Alejandro (2005). Derecho administrativo sancionador. $4^{\circ}$ edición. Tecnos, Madrid. 
NovoA, Eduardo (2005). Curso de Derecho Penal Chileno. tomo I, $3^{a}$ edición, Editorial Jurídica de Chile, Santiago.

Oksenberg González, Daniel y Flores Fernández, Cristián (2009). «Principios de legitimación del ius puniendi estatal en el derecho administrativo sancionador: revisión crítica» [en línea], Universidad de Chile, Facultad de Derecho, Santiago, Chile [Fecha consulta: 12 de abril 2017].

Ossandón Widow, María Magdalena (2015). «El principio ne bis in idem en el sistema jurídico chileno. Análisis de la jurisprudencia constitucional 2015» en: Revista de ciencias penales, v.42 n.3, 87-110.

Pantoja, Rolando (200o). Estatuto Administrativo Interpretado, Sistematizado y Comentado, Editorial Jurídica de Chile, Santiago.

Peman Gavín, Ignacio (200o). El sistema sancionador español. Hacia una teoría de las Infracciones y Sanciones Administrativas, $1^{\circ}$ edición, Editorial Cedecs, Barcelona.

Politoff, Sergio (1997). Derecho Penal. Tomo I, Editorial Jurídica Cono Sur, Santiago de Chile.

PritTwitz, Cornelius (2000). «El Derecho penal alemán: ¿fragmentario? ¿subsidiario? ¿última ratio?, en La Insostenible situación del Derecho penal, Editorial Comares, Granada, pp. 427-446.

Ramos, Isabel (2005). «El principio de personalidad de la pena en el Derecho histórico castellano», en. Revista de la Inquisición (Intolerancia y Derechos Humanos), No 11.

RaINer, Arnold; Martínez, José Ignacio y Zúniga, Francisco (2012). «El principio de proporcionalidad en la jurisprudencia del Tribunal Constitucional», en Estudios Constitucionales, Año 10, № ${ }_{1}$, Centro de Estudios Constitucionales de Chile, Universidad de Talca.

Ríos, Rodrigo y Ortiz, Pablo (2011). Ganancias Ilícitas. Una revisión crítica a su tratamiento legal en Chile, Editorial Universidad Finis Terrae, Santiago.

Rodríguez Arana, Jaime (2011). «Discrecionalidad y motivación del acto administrativo en la ley española de procedimiento administrativo», en Revista de Derecho Pontifica Universidad Católica del Perú, $\mathrm{N}^{\circ} 67$.

Rodríguez Collao, Luis (1987). «Bases para distinguir entre infracciones criminales y administrativas», en Revista de Derecho de la Universidad Católica de Valparaíso, vol. XI.

Rojas CALderón, Christian (2014). Las potestades administrativas en el derecho chileno. Santiago, Legal Publishing/Thomson Reuters, Santiago.

RomÁn Cordero, Cristian (2008). «Derecho Administrativo Sancionador: «¿Ser o no ser? He ahí el dilema»», en Derecho Administrativo 120 Años de Cátedra, Editorial Jurídica de Chile, Santiago, pp. 107-141.

-. (2009). «El debido procedimiento administrativo sancionador», en Revista de Derecho Público, $\mathrm{N}^{\circ} 71$. 
Romero GuZmán, Juan José (2005). «¿Cuándo hay un buen sistema regulatorio? Criterios de legitimidad», en Actas XXXIV Jornadas de Derecho Público, 25 - 27 de noviembre de 2004. Facultad de Derecho Pontificia Universidad Católica de Chile, $1^{\text {a }}$ Edición, pp. 539-554.

Romero Seguel, Alejandro (2011). «Algunos privilegios procesales de la administración del Estado en la litigación civil (dos mecanismos para su atenuación o supresión)», en Arancibia Mattar, Jaime; Martínez Estay, José Ignacio y Romero Seguel, Alejandro (coordinadores): Litigación Pública. Thomson Reuters, Santiago, p. 437- 467.

Roxin, Claus (1997). Derecho penal. Parte general, Tomo I, Civitas, Madrid.

Santamaría Pastor, Juan Alfonso (2009). Principios de Derecho Administrativo. II, $2^{\circ}$ edición, Iustel, Madrid.

SEgURA, Romina (2014). «Naturaleza jurídica y fundamento constitucional de la potestad punitiva de la administración del Estado», en Revista de Derechos Fundamentales, Universidad Viña del Mar, $\mathrm{N}^{\circ}$ 11, pp. 163-194.

Silva Cimma, Enrique (2008). Derecho Administrativo Sancionador Chileno y Comparado, Introducción y Fuentes. $4^{\circ}$ edición. Editorial Jurídica de Chile, Santiago.

-. (1993). Derecho Administrativo Chileno y Comparado. La Función Pública, Editorial Jurídica de Chile Santiago.

Silva Sánchez, Jesús (2011). La expansión del Derecho Penal. Aspectos de Política Criminal en las sociedades postindustriales. $3^{\circ}$ Edición, Editorial BdeF, MontevideoBuenos Aires.

Sото KLoss, Eduardo (2006). «La impugnación de sanciones administrativas y el derecho fundamental de acceso a la justicia: El «Solve et Repete» y El Estado de Derecho», en Sanciones Administrativas y Derechos Fundamentales, Conferencias Santo Tomás de Aquino. Santiago. Academia de Derecho Universidad Santo Tomás.

-. (2005). «Sanciones Administrativas ¿camino de servidumbre?», en Gaceta Jurídica. Editorial Lexis Nexis. Santiago, № 296, pp. 76- 88.

-. (1979/1980). «Derecho Administrativo Penal. Notas para el estudio de la potestad sancionadora de la Administración», en Boletín de Investigaciones, Facultad de Derecho de la Pontificia Universidad Católica de Chile ( $\mathrm{N}^{\circ}$ 44-45), pp. 95-103.

-. (2014). «Otra vez sobre la potestad sancionatoria de la administración», en Sanciones Administrativas. Arancibia, Jaime y Alarcón, Pablo (coordinadores), Editorial Legal Publishing-Universidad de los Andes, Santiago, pp. 39 y ss.

Soto, Pablo (2016). «Sanciones administrativas como medidas de cumplimiento del Derecho: un enfoque funcional y responsivo aplicado al régimen sancionatorio ambiental», en Revista Ius et Praxis, Año 22, № 2.

Tiedemann, Klaus (1993). Lecciones de Derecho Penal Económico, Editorial PPU, Barcelona. 
Van Weezel, Alex (2011). La garantía de tipicidad en la jurisprudencia del Tribunal Constitucional, Abeledo Perrot Legal Publishing Chile, Thomson Reuters, Santiago.

Vergara, Alejandro (2004). «Esquema de los principios del Derecho administrativo sancionador», en Revista de Derecho, Universidad Católica del Norte, año 11, (No 2), pp. 137-147.

-. (2004). «Principios del ius puniendi que debe respetar la SEC», en Revista «Electricidad Interamericana», $\mathrm{N}^{\circ} 76$.

-. (2009). «Derecho Administrativo y supuesta supletoriedad del Código Civil», en Revista de Derecho Administrativo, No 3 , Legal Publishing, Santiago, pp. 45-68.

Winter, Jaime (2013). «Derecho Penal e Impunidad Empresarial en Chile», en Revista de Estudios de la Justicia, (19): 91-125.

Zaffaroni, Eugenio (2002). Derecho Penal. Parte General. $2^{\circ}$ edición. Ediar, Buenos Aires.

ZÚÑIGA, Francisco (2015). «El Retorno a lo administrativo: Comentario a la sentencia Rol N 1079-2014 de la Corte Suprema, «Fisco con Dörr Zegers y otros» («Chispas II»)», en Revista de Estudios Constitucionales, año 13.

\section{Sobre el autor}

Pedro Aracena Salgado es abogado. Su correo electrónico es pedroaracena@ gmail.com. 